\title{
11. DETECTION OF METHANE GAS HYDRATE IN THE PRESSURE CORE SAMPLER (PCS): VOLUME-PRESSURE-TIME RELATIONS DURING CONTROLLED DEGASSING EXPERIMENTS ${ }^{1}$
}

\author{
Gerald R. Dickens, ${ }^{2}$ Paul J. Wallace, ${ }^{3}$ Charles K. Paull, ${ }^{4,5}$ Walter S. Borowski ${ }^{4,6}$
}

\begin{abstract}
A pressurized core with $\mathrm{CH}_{4}$ hydrate or dissolved $\mathrm{CH}_{4}$ should evolve gas volumes in a predictable manner as pressure is released over time at isothermal conditions. Incremental gas volumes were collected as pressure was released over time from 29 pressure core sampler (PCS) cores from Sites 994, 995, 996, and 997 on the Blake Ridge. Most of these cores were kept at or near $0^{\circ} \mathrm{C}$ with an ice bath, and many of these cores yielded substantial quantities of $\mathrm{CH}_{4}$. Volume-pressure plots were constructed for 20 of these cores. Only five plots conform to expected volume and pressure changes for sediment cores with $\mathrm{CH}_{4}$ hydrate under initial pressure and temperature conditions. However, other evidence suggests that sediment in these five and at least five other PCS cores contained $\mathrm{CH}_{4}$ hydrate before core recovery and gas release. Detection of $\mathrm{CH}_{4}$ hydrate in a pressurized sediment core through volume-pressure relationships is complicated by two factors. First, significant quantities of $\mathrm{CH}_{4}^{-}$ poor borehole water fill the PCS and come into contact with the core. This leads to dilution of $\mathrm{CH}_{4}$ concentration in interstitial water and, in many cases, decomposition of $\mathrm{CH}_{4}$ hydrate before a degassing experiment begins. Second, degassing experiments were conducted after the PCS had equilibrated in an ice-water bath $\left(0^{\circ} \mathrm{C}\right)$. This temperature is significantly lower than in situ values in the sediment formation before core recovery. Our results and interpretations for PCS cores collected on Leg 164 imply that pressurized containers formerly used by the Deep Sea Drilling Project (DSDP) and currently used by ODP are not appropriately designed for direct detection of gas hydrate in sediment at in situ conditions through volume-pressure relationships.
\end{abstract}

\section{INTRODUCTION}

The Blake Ridge is a large sediment drift deposit in the Atlantic Ocean off the east coast of the United States (Paull, Matsumoto, Wallace, et al., 1996, p. 5). The primary objective of Ocean Drilling Program (ODP) Leg 164 was to understand the amount and distribution of natural gas hydrate in sediment pore space at three sites (Sites 994, 995, and 997) on the crest of this ridge $200 \mathrm{~km}$ from the coast (Paull, Matsumoto, Wallace, et al., 1996). Critical to this endeavor was the testing of various techniques to detect the presence (or absence) of gas hydrate.

Hunt (1979, p. 160-161) presented an intriguing theoretical approach for identifying gas hydrate in sediment cores under pressure. The technique involves measurement of incremental gas volumes slowly released from a pressurized core, and subsequent comparison of observed volume and pressure changes to expected curves (see below). Kvenvolden et al. (1983) attempted this experiment at Deep Sea Drilling Project (DSDP) Site 533 but could not recover incremental gas volumes for a rigorous evaluation of the technique. Instead, they constructed time-pressure plots and made tentative interpretations concerning the presence or absence of gas hydrate on the basis of these alternative plots.

${ }^{1}$ Paull, C.K., Matsumoto, R., Wallace, P.J., and Dillon, W.P. (Eds.), 2000. Proc. $O D P$, Sci. Results, 164: College Station, TX (Ocean Drilling Program).

${ }^{2}$ School of Earth Sciences, James Cook University, Townsville, QLD 4811 Australia.Jerry.Dickens@jcu.edu.au U.S.A.

Ocean Drilling Program, Texas A\&M University, College Station, TX 77845,

${ }^{4}$ Department of Geology, University of North Carolina, Chapel Hill, NC 275993315, U.S.A

${ }^{5}$ Present address: Monterey Bay Aquarium Research Institute, 7700 Sandholdt Road, Moss Landing, CA 95039-0628, U.S.A.

${ }^{6}$ Present address: Exxon Exploration Company, P.O. Box 4778, Houston, TX 77210-4778, U.S.A.
Forty-two cores were successfully recovered at high pressure with the pressure core sampler (PCS) during Leg 164 (Dickens et al., Chap. 43, this volume). Twenty-nine of these PCS cores were connected to a gas manifold system especially designed to collect incremental gas volumes over time (Paull, Matsumoto, Wallace, et al., 1996, pp. 24-26). Here we present volume-pressure plots for 20 of these cores. Our interpretation of these plots is more complex than those discussed previously (Hunt, 1979; Kvenvolden et al., 1983). In particular, we demonstrate that effects related to the coring process and differences between in situ and experimental conditions make it difficult to unambiguously detect the presence of $\mathrm{CH}_{4}$ hydrate in pressurized sediment cores.

\section{THEORETICAL BACKGROUND}

The theoretical approach of Hunt (1979) for detecting gas hydrate in a pressurized sediment core can be illustrated by considering pressure-temperature, pressure-composition (molality), and pressurevolume phase diagrams for the $\mathrm{CH}_{4}$-water system (Figs. 1-3). Figure 1 is a temperature-pressure phase diagram for $\mathrm{CH}_{4}$ and water at high gas concentration. Figure 2 is a concentration (molality)-pressure phase diagram for $\mathrm{CH}_{4}$ and water at constant temperature. Figure 3 is a volume-pressure plot concerning the expected volume of $\mathrm{CH}_{4}$ gas released from a pressurized core of known volume at constant temperature. For simplicity and convenience, these figures pertain to the pure $\mathrm{CH}_{4}$-pure water and pure $\mathrm{CH}_{4}$-seawater $(\mathrm{S}=35)$ systems (Handa, 1990; Dickens and Quinby-Hunt, 1994; Tohidi et al., 1995). The ensuing treatise is provided because the technique of Hunt (1979) has not been thoroughly discussed in the literature, and because it is necessary for understanding limitations to the approach.

A core with sediment and pore water (pure water or seawater in this discussion) is collected at depth in a pressure container of known volume at an initial time $t_{0}$ with a given pressure, temperature, and $\mathrm{CH}_{4}$ quantity. At temperatures and pressures in the hydrate stability 


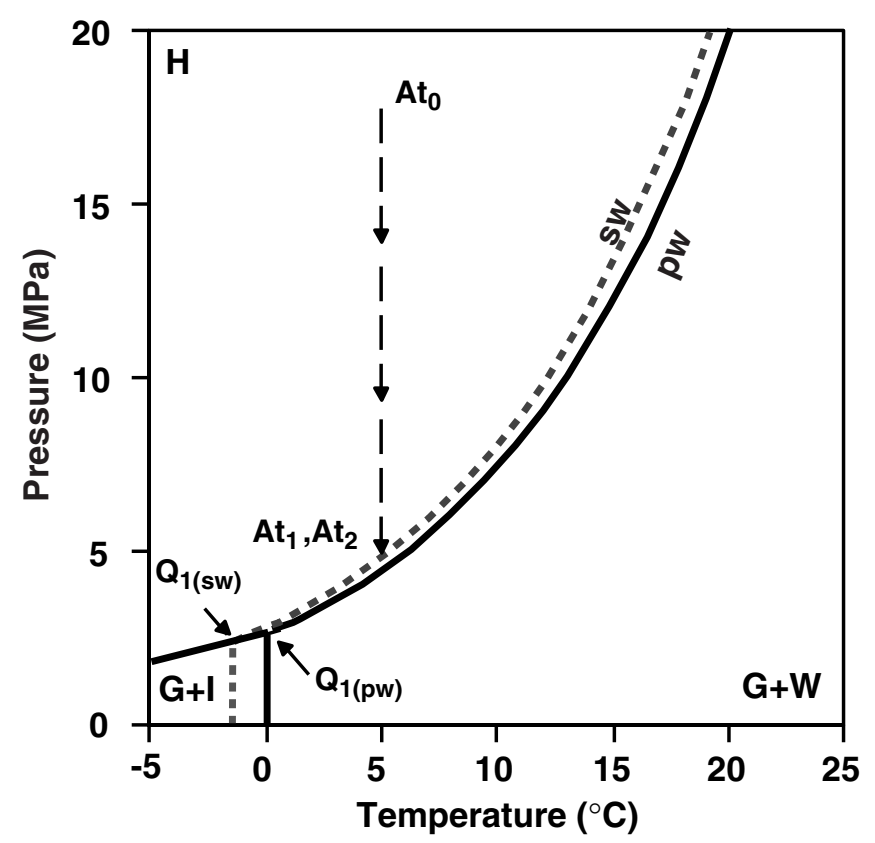

Figure 1. Temperature-pressure phase diagrams for the pure $\mathrm{CH}_{4}$-pure water (pw) and pure $\mathrm{CH}_{4}$-seawater (sw) systems at high $\mathrm{CH}_{4}$ concentration (Dickens and Quinby-Hunt, 1994). There are four phases- $-\mathrm{CH}_{4}$ gas (G), $\mathrm{CH}_{4}$ hydrate $(\mathrm{H})$, water $(\mathrm{W})$, and ice (I) - separated by three equilibrium curves. The intersection of the equilibrium curves is the quadruple point $\left(\mathrm{Qa}_{1}\right)$. A core recovered at high pressure and moderate temperature will change positions on this diagram as pressure is released over time. Path $\mathrm{A}$ is the expected change in position for a core maintained at constant temperature of $5^{\circ} \mathrm{C}$ as pressure is decreased from initial pressure of $18 \mathrm{MPa}$ at $\mathrm{At}_{0}$ to $4.95 \mathrm{MPa}$ at $\mathrm{At}_{1}$ and $\mathrm{At}_{2}$ (see text). This phase diagram is not appropriate at low $\mathrm{CH}_{4}$ concentrations during the pressure decrease from $\mathrm{At}_{2}$ to $\mathrm{At}_{3}$ (see Fig. 2).

field and sufficiently high $\mathrm{CH}_{4}$ concentration, the core at $\mathrm{t}_{0}$ should contain $\mathrm{CH}_{4}$ hydrate and water saturated with $\mathrm{CH}_{4}$ (Path A, Figs. 1, 2 ). Alternatively, under the same pressure and temperature conditions, if $\mathrm{CH}_{4}$ concentration is low, the core at $\mathrm{t}_{0}$ should contain water undersaturated with $\mathrm{CH}_{4}$ (Path B, Fig. 2 [cannot be shown in Fig. 1]). Although a pressurized core at moderate temperature and very high $\mathrm{CH}_{4}$ concentrations could contain $\mathrm{CH}_{4}$ hydrate, free $\mathrm{CH}_{4}$ gas, and solid salt in the pure water-seawater system (Handa, 1990), this case is unlikely in the marine environment because the gas to water ratio will be relatively low (except, perhaps at the microscopic scale or in unusual environments like mud volcanoes).

As pressure is initially released from either a hydrate-bearing or hydrate-free core under isothermal conditions ( $\mathrm{t}_{0}$ to $\mathrm{t}_{1}$ in Figs. 1, 2), concentration of $\mathrm{CH}_{4}$ should not decrease because all $\mathrm{CH}_{4}$ remains in $\mathrm{CH}_{4}$-saturated water or $\mathrm{CH}_{4}$ hydrate. However, once a pressure along the hydrate saturation curve is reached ( $\mathrm{t}_{1}$ in Figs. 1, 2), cores containing $\mathrm{CH}_{4}$ hydrate should display a different behavior during isothermal degassing than cores with only dissolved $\mathrm{CH}_{4}$. Consider a core containing hydrate at a temperature and pressure on the $\mathrm{CH}_{4}$ gas- $\mathrm{CH}_{4}$ hydrate-water equilibrium curve (Figs. 1, 2). As pressure is released across the three-phase equilibrium curve, hydrate dissociates to $\mathrm{CH}_{4}$ gas and water. Because of the large volume increase in going from solid $\mathrm{CH}_{4}$ hydrate to $\mathrm{CH}_{4}$ gas, degassing of $\mathrm{CH}_{4}$ can occur under isobaric and isothermal conditions from $\mathrm{t}_{1}$ to $\mathrm{t}_{2}$ provided infinitely small volumes of $\mathrm{CH}_{4}$ gas are released from the container (Figs. 1, 2). In contrast, degassing of $\mathrm{CH}_{4}$ cannot occur isobarically for a core that does not initially contain hydrate (Fig. 2).

At $\mathrm{t}_{2}$, temperature, concentration and pressure are on a $\mathrm{CH}_{4}$-water saturation curve (Fig. 2). As pressure is released at this point for a core with gas hydrate $\left(\mathrm{At}_{2}, \mathrm{Path} \mathrm{A}\right)$, the remaining quantity of hydrate

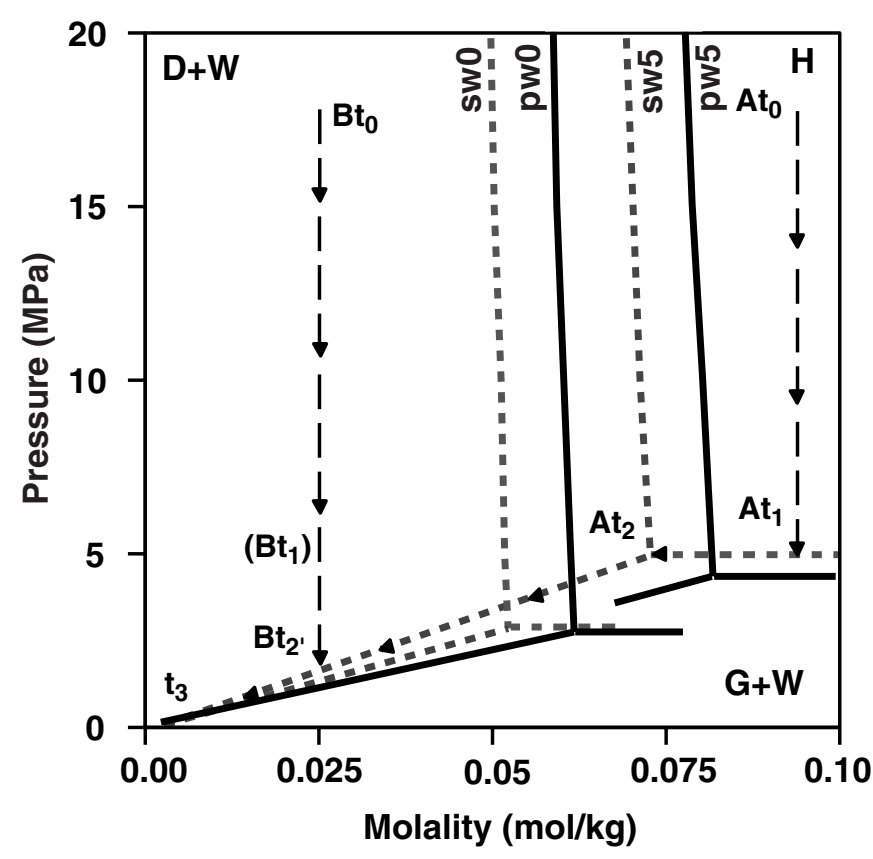

Figure 2. Concentration-pressure phase diagrams for pure $\mathrm{CH}_{4}$-pure water (pw) and pure $\mathrm{CH}_{4}$-seawater (sw) systems at constant temperatures of $0^{\circ} \mathrm{C}$ and $5^{\circ} \mathrm{C}$ (Handa, 1990; Dickens and Quinby-Hunt, 1994). There are three phases $-\mathrm{CH}_{4}$ gas $(\mathrm{G}), \mathrm{CH}_{4}$ hydrate $(\mathrm{H})$, and water with dissolved $\mathrm{CH}_{4}(\mathrm{~W})$ separated by three equilibrium curves. The intersection of the equilibrium curves exists for seawater at $0.052 \mathrm{~mol} / \mathrm{kg}$ and $2.89 \mathrm{MPa}$ at $0^{\circ} \mathrm{C}$, and 0.072 $\mathrm{mol} / \mathrm{kg}$ and $4.95 \mathrm{MPa}$ at $5^{\circ} \mathrm{C}$ (Handa, 1990). Note that experimental data for equilibrium curves separating $\mathrm{CH}_{4}$-hydrate $(\mathrm{H})$ and $\mathrm{CH}_{4}$ gas undersaturated water $(\mathrm{W})$ are unavailable and that points defining these "partial saturation" curves are theoretical (Handa, 1990). Note also that gas and water will be in equilibrium with ice (I) in the case of pure water and $\mathrm{CH}_{4}$ at $0^{\circ} \mathrm{C}$ (see Fig. 1). A core recovered at high pressure will change positions on this diagram as pressure is released through incremental gas volume loss over time. Path A is the expected change in position for a core with initial $\mathrm{CH}_{4}$ molality of 0.09 $\mathrm{mol} / \mathrm{kg}$ maintained at constant temperature of $5^{\circ} \mathrm{C}$ as pressure is decreased from initial pressure of $18 \mathrm{MPa}$ at $\mathrm{At}_{0}$ to $4.95 \mathrm{MPa}$ at $\mathrm{At}_{1}$ and $\mathrm{At}_{2}$, and to 0.10 $\mathrm{MPa}$ at $\mathrm{t}_{3}$. Path $\mathrm{B}$ is the expected change in position for a core with an initial $\mathrm{CH}_{4}$ molality of $0.025 \mathrm{~mol} / \mathrm{kg}$ maintained at constant temperature of $5^{\circ} \mathrm{C}$ as pressure is decreased from initial pressure of $18 \mathrm{MPa}$ at $\mathrm{Bt}_{0}$ to $1.71 \mathrm{MPa}$ at $\mathrm{Bt}_{2}{ }^{\prime}$ and to $0.10 \mathrm{MPa}$ at $\mathrm{t}_{3}$. Note that a core following Path $\mathrm{A}$ would contain gas hydrate and dissolved gas in seawater at initial conditions, whereas a core following Path $\mathrm{B}$ would contain only dissolved $\mathrm{CH}_{4}$ in seawater.

dissociates to $\mathrm{CH}_{4}$ gas, and then there is only gas saturated water, a situation similar to that for a core that did not have gas hydrate in the first place $\left(\mathrm{Bt}_{2}\right.$, Path $\left.\mathrm{B}\right)$. Continued decompression will move the system down the gas-saturation curve (Fig. 2).

Concentration of $\mathrm{CH}_{4}$ and pressure should decrease under isothermal conditions from $t_{2}$ to $t_{3}$ (Fig. 2). The reason is simple: pressure is directly proportional to gas concentration at these pressure and temperature conditions (Henry's Law).

Characteristic volume-pressure plots (Fig. 3) should result after slow and isothermal release of $\mathrm{CH}_{4}$ from pressurized cores that contained sediment, pore water, and $\mathrm{CH}_{4}$ at initial experimental conditions (Hunt, 1979; Kvenvolden et al., 1983). Minimal volumes of $\mathrm{CH}_{4}$ should be released from containers during the pressure drop between $t_{0}$ and $t_{1}$ for cores with gas hydrate or $t_{0}$ and $t_{2}$ for cores without gas hydrate (Fig. 3). The reason is twofold: (1) essentially all $\mathrm{CH}_{4}$ during the pressure drop is in hydrate or dissolved in water; and (2) a two phase $\mathrm{CH}_{4}-\mathrm{CH}_{4}$ hydrate saturation curve is nearly vertical in concentration-pressure space (Fig. 2; Handa, 1990; Tohidi et al., 1995). 


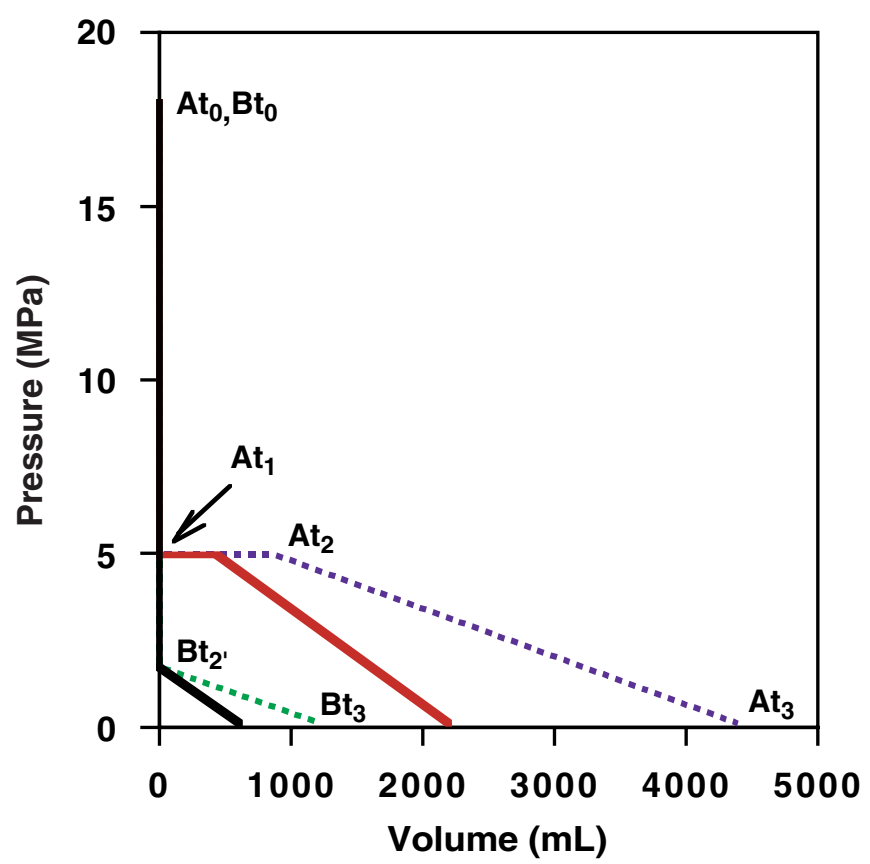

Figure 3. Expected volume-pressure curves for cores with (Path A) $\mathrm{CH}_{4}$ hydrate and dissolved $\mathrm{CH}_{4}$ in seawater, and (Path B) only dissolved $\mathrm{CH}_{4}$ in seawater as pressure is released through incremental gas volume loss over time at isothermal conditions (here $5^{\circ} \mathrm{C}$ ). Initial conditions for Path A cores are $\mathrm{CH}_{4}$ molality of $0.09 \mathrm{~mol} / \mathrm{kg}$ and pressure of $18 \mathrm{MPa}$; initial conditions for Path B cores are $\mathrm{CH}_{4}$ molality of $0.025 \mathrm{~mol} / \mathrm{kg}$ and pressure of $18 \mathrm{MPa}$. Solid lines represent cores with a water volume of $1 \mathrm{~L}$, whereas stippled lines represent cores with a water volume of $2 \mathrm{~L}$. Note that this figure has been significantly modified from original figure by Hunt (1979, p. 161).

Volumes of $\mathrm{CH}_{4}$ should be released from containers with gas hydrate at constant pressure during the concentration drop between $\mathrm{At}_{1}$ and $\mathrm{At}_{2}$ (Fig. 3), because gas removal is driving hydrate dissociation. Volumes of $\mathrm{CH}_{4}$ should be released from containers at decreasing pressure during the concentration drop between $t_{2}$ and $t_{3}$ (Fig. 3), because gas removal causes gas to be released from solution. Actual volumes of $\mathrm{CH}_{4}$ released during these pressure and concentration changes depend on the volume of water inside of the container (Fig. 3).

In theory, amounts of $\mathrm{CH}_{4}$ in hydrate and dissolved in water could be determined from volume-pressure plots. The quantity of $\mathrm{CH}_{4}$ stored in hydrate would be the volume released under isobaric conditions $\left(t_{1}\right.$ to $t_{2}$ ); the quantity of $\mathrm{CH}_{4}$ dissolved in water would be the volume released under decreasing pressure conditions $\left(t_{2}\right.$ to $\left.t_{3}\right)$. In principle, in situ pore-water salinity (at least the effective salinity) also could be determined from volume-pressure plots because pressure at $t_{1}$ and $t_{2}$ depends on the activity of water (e.g., Handa, 1990; Dickens and Quinby-Hunt, 1997). However, it would be difficult to assess this subtle effect, which would further be complicated by additional gas components (e.g., $\mathrm{CO}_{2}$ ).

\section{SAMPLE DESCRIPTION AND DATA COLLECTION}

The pressure core sampler (PCS) is a tool designed to recover a $1385-\mathrm{cm}^{3}$ cylindrical sediment core at in situ pressure (Pettigrew, 1992). Forty-two deployments (runs) of the PCS on Leg 164 successfully recovered core at pressures greater than $3.45 \mathrm{MPa}$ (Paull, Matsumoto, Wallace, et al., 1996; Dickens et al., Chap. 43, this volume). Incremental volumes were determined for 29 of these cores at Sites 994, 995, 996, and 997 as pressure was released over time (Table 1).
Ten of the 29 cores most likely contained gas hydrate filling more than $1 \%$ porosity at in situ pressure, temperature, and gas concentration (Table 1). These 10 PCS cores (labeled "Cl" or "S" in Table 1) were recovered from sediment regions where all available information indicates the presence of in situ gas hydrate. The inference is made for PCS cores at Sites 995 and 997 on the basis of interpretations of well-log resistivity and velocity, interstitial water $\mathrm{Cl}^{-}$concentrations, and vertical seismic profiling (Holbrook et al., 1996; Paull, Matsumoto, Wallace, et al., 1996), as well as our interpretation of PCS data (see "Discussion" section and Dickens et al., 1997). The inference is made for PCS cores at Site 996 because nonpressurized sediment cores contained abundant visible gas hydrate specimens (Paull, Matsumoto, Wallace, et al., 1996). An additional six of the 29 PCS cores (labeled "Q" in Table 1) were recovered from sediment regions where certain interpretations of data suggest that in situ gas hydrate was present (cf. Holbrook et al., 1996; Paull, Matsumoto, Wallace, et al., 1996; Egeberg and Dickens, 1999).

Data collection for the 29 PCS runs of interest generally proceeded as follows (Paull, Matsumoto, Wallace, et al., 1996; Dickens et al., Chap. 43, this volume). The PCS was placed in an ice bath after core recovery. A gas manifold system (PCS-M3B or PCS-M4; Paull, Matsumoto, Wallace, et al., 1996, pp. 24-26) and sampling chamber were attached to a port on the PCS. Incremental volumes of gas were released from the PCS over time until the inside of the PCS was at atmospheric pressure. The PCS was removed from the ice bath and warmed to ambient temperature $\left(\sim 15^{\circ} \mathrm{C}\right)$. Additional volumes of gas were then collected. Aliquots of gas were taken from many gas volume increments for compositional analyses. The PCS was opened, and the sediment core was examined for volume and physical properties measurements.

Errors in individual gas volume and pressure measurements were within $10 \mathrm{~mL}$ and $10 \mathrm{psi}(0.07 \mathrm{MPa})$, respectively; errors in measured core lengths were within $1 \mathrm{~cm}$.

It is stressed, however, that there was a lack of experimental consistency with PCS operations on Leg 164 due to a variety of technical and operational reasons. For example (Dickens et al., Chap. 43, this volume), five cores were not maintained at isothermal $\left(0^{\circ} \mathrm{C}\right)$ conditions (Cores 164-995A-52P*, 164-995A-70P, 164-996E-8P, 164-997A-25P, and 164-997B-10P); most cores were not given sufficient time to equilibrate after changes in pressure (and gas concentration); the manifold port connection for many cores had to be switched during the middle of gas release experiments; and individual cores had different initial pressures, temperatures, gas concentrations, and sediment volumes. In summary (and as highlighted in the "Discussion" section), each core needs to be considered separately for experimental artifacts and errors. Some of the potential problems are noted in Tables 1 and 2 (and notes for Fig. 4); additional problems can be identified by examining records of individual PCS cores (Paull, Matsumoto, Wallace, et al., 1996; Dickens et al., Chap. 43, this volume).

\section{RESULTS AND VOLUME-PRESSURE PLOTS}

Volume, pressure, and time information collected during stepwise gas release from each PCS core are presented by Dickens et al. (Chap. 43, this volume). Using this data, we have constructed volume-pressure (VP) plots for 20 PCS cores (Fig. 4). Seven of the 29 cores recovered at high pressure (Cores 164-995A-0P*, 164-995A52P*, 164-997B-29P*, 164-997B-32P, 164-997B-36P, 164-997B$40 \mathrm{P}$, and $164-997 \mathrm{~B}-44 \mathrm{P})$ released only a small volume of air with a decrease in pressure to atmospheric conditions. These seven cores did not contain sediment or $\mathrm{CH}_{4}$. An additional two cores (Cores 164995A-70P and 164-996E-8P) were not placed in an ice bath, and thus degassing of these cores was not isothermal.

Volumes used to make the volume-pressure plots include gas volumes released at all temperatures $\left(0^{\circ}-15^{\circ} \mathrm{C}\right)$; pressures used to make 
Table 1. Description of PCS cores used for gas-release experiments.

\begin{tabular}{|c|c|c|c|c|c|c|c|c|c|c|}
\hline Core & $\begin{array}{l}\text { Part of } \\
\text { Fig. } 4\end{array}$ & $\begin{array}{l}\text { Depth } \\
\text { (mbsf) }\end{array}$ & $\begin{array}{c}\text { Recovered } \\
\text { pressure } \\
(\mathrm{MPa})\end{array}$ & $\begin{array}{c}\text { Cold } \\
\text { pressure } \\
(\mathrm{MPa})\end{array}$ & $\begin{array}{l}\text { Total } \\
\text { time } \\
(\mathrm{min})\end{array}$ & $\begin{array}{c}0^{\circ} \mathrm{C} \\
\underset{(\mathrm{min})}{\text { equilibrate }}{ }^{\dagger}\end{array}$ & $\begin{array}{c}0^{\circ} \mathrm{C} \\
\text { end }^{\S} \\
(\min )\end{array}$ & $\begin{array}{l}\text { Chamber } \\
\text { sampled }\end{array}$ & $\begin{array}{c}\text { Core } \\
\text { length } \\
(\mathrm{cm})\end{array}$ & $\begin{array}{c}\text { In situ } \\
\text { hydrate } \\
\text { evidence }\end{array}$ \\
\hline $\begin{array}{l}164-994 \mathrm{C}- \\
70 \mathrm{P}\end{array}$ & A & 569.9 & 29.4 & 23.3 & 1158 & 1139 & 1158 & Inner & 20 & None \\
\hline $\begin{array}{l}164-995 \mathrm{~A}- \\
0 \mathrm{P}^{*} \\
18 \mathrm{P} \\
27 \mathrm{P} \\
36 \mathrm{P} \\
45 \mathrm{P} \\
48 \mathrm{P} \\
52 \mathrm{P}^{*} \\
52 \mathrm{P} \\
60 \mathrm{P} \\
70 \mathrm{P}\end{array}$ & $\begin{array}{l}\bar{B} \\
C \\
D \\
E \\
F \\
G \\
H \\
\end{array}$ & $\begin{array}{l}-73.0 \\
136.7 \\
223.9 \\
301.3 \\
378.6 \\
397.8 \\
423.7 \\
426.7 \\
494.1 \\
589.2\end{array}$ & $\begin{array}{l}19.0 \\
21.9 \\
27.9 \\
32.7 \\
31.2 \\
32.4 \\
33.3 \\
33.0 \\
29.2 \\
25.2\end{array}$ & $\begin{array}{c}13.1 \\
16.7 \\
19.8 \\
27.7 \\
27.2 \\
27.3 \\
\text { No ice } \\
25.7 \\
22.8 \\
\text { No ice }\end{array}$ & $\begin{array}{l}120 \\
186 \\
416 \\
344 \\
281 \\
254\end{array}$ & $\begin{array}{c}107 \\
110 \\
152 \\
138 \\
65 \\
98 \\
\text { No ice } \\
152 \\
134 \\
\text { No ice }\end{array}$ & $\begin{array}{c}120 \\
186 \\
377 \\
279 \\
132 \\
165 \\
\text { No ice } \\
183 \\
178 \\
\text { No ice }\end{array}$ & $\begin{array}{l}\text { Inner } \\
\text { Inner } \\
\text { Inner-outer } \\
\text { Inner } \\
\text { Inner-outer } \\
\text { Inner-outer } \\
\text { Inner } \\
\text { Inner } \\
\text { Inner-outer } \\
\text { Inner }\end{array}$ & $\begin{array}{r}0 \\
70 \\
100 \\
75 \\
58 \\
23 \\
0 \\
18 \\
9 \\
3\end{array}$ & $\begin{array}{l}\text { None } \\
\mathrm{Q} \\
\mathrm{Cl}, \mathrm{Cl} \neq, \mathrm{R} \\
\mathrm{Q} \\
\mathrm{Cl}, \mathrm{R} \\
\mathrm{Cl}, \mathrm{R} \\
\mathrm{None}^{\#} \\
\mathrm{Cl}, \mathrm{R} \\
\text { None } \\
\text { None }\end{array}$ \\
\hline $\begin{array}{l}\text { 164-995B- } \\
7 \mathrm{P} \\
10 \mathrm{P}\end{array}$ & $\begin{array}{l}\mathrm{I} \\
\mathrm{J}\end{array}$ & $\begin{array}{l}308.5 \\
320.5\end{array}$ & $\begin{array}{l}19.1 \\
22.5\end{array}$ & $\begin{array}{l}13.2 \\
17.1\end{array}$ & $\begin{array}{r}230 \\
1153\end{array}$ & $\begin{array}{r}75 \\
276\end{array}$ & $\begin{array}{l}230 \\
420\end{array}$ & $\begin{array}{l}\text { Inner-outer } \\
\text { Inner-outer }\end{array}$ & $\begin{array}{l}93 \\
65\end{array}$ & $\begin{array}{l}\mathrm{Q} \\
\mathrm{Q}, \mathrm{Cl} \text { }\end{array}$ \\
\hline $\begin{array}{l}\text { 164-996A- } \\
7 \mathrm{P}\end{array}$ & $\mathrm{K}$ & 47.5 & 22.9 & 17.5 & 1475 & 623 & 1324 & Inner & 20 & $\mathrm{~S}$ \\
\hline $\begin{array}{l}\text { 164-996D- } \\
7 \mathrm{P}\end{array}$ & $\mathrm{L}$ & 51.2 & 20.5 & 16.2 & 1235 & 99 & 1073 & Inner & 0 & $\mathrm{~S}$ \\
\hline $\begin{array}{l}\text { 164-996E- } \\
8 \mathrm{P}\end{array}$ & - & 61.3 & 6.5 & No ice & & No ice & No ice & Inner & 0 & $S$ \\
\hline $\begin{array}{c}164-997 \mathrm{~A}- \\
18 \mathrm{P} \\
25 \mathrm{P} \\
33 \mathrm{P} \\
49 \mathrm{P} \\
55 \mathrm{P}\end{array}$ & $\begin{array}{l}\mathrm{M} \\
\mathrm{N} \\
\mathrm{O} \\
\mathrm{P} \\
\mathrm{Q}\end{array}$ & $\begin{array}{l}146.9 \\
202.4 \\
317.7 \\
394.9 \\
433.3\end{array}$ & $\begin{array}{r}29.6 \\
31.0 \\
33.1 \\
25.3 \\
5.2\end{array}$ & $\begin{array}{r}23.9 \\
26.5 \\
26.8 \\
20.7 \\
3.0\end{array}$ & $\begin{array}{l}378 \\
375 \\
456 \\
281 \\
741\end{array}$ & $\begin{array}{r}156 \\
99 \\
185 \\
64 \\
180\end{array}$ & $\begin{array}{l}233 \\
259 \dagger \dagger \\
254 \\
222 \\
306\end{array}$ & $\begin{array}{l}\text { Inner-outer } \\
\text { Inner } \\
\text { Inner } \\
\text { Outer } \\
\text { Inner-outer }\end{array}$ & $\begin{array}{r}42 \\
88 \\
0 \\
64 \\
50\end{array}$ & $\begin{array}{l}\mathrm{Q} \\
\mathrm{Cl}, \mathrm{Cl} \neq, \mathrm{R} \\
\mathrm{Q} \\
\mathrm{Cl}, \mathrm{R} \\
\mathrm{Cl}, \mathrm{Cl} \neq, \mathrm{R}\end{array}$ \\
\hline $\begin{array}{l}164-997 \mathrm{~B}- \\
10 \mathrm{P} \\
15 \mathrm{P} \\
21 \mathrm{P} \\
29 \mathrm{P} * \\
32 \mathrm{P} \\
36 \mathrm{P} \\
40 \mathrm{P} \\
44 \mathrm{P}\end{array}$ & $\begin{array}{l}\mathrm{R} \\
\mathrm{S} \\
\mathrm{T} \\
-\mathrm{C} \\
- \\
-\end{array}$ & $\begin{array}{l}462.2 \\
501.8 \\
549.9 \\
606.5 \\
635.3 \\
664.1 \\
693.0 \\
721.8\end{array}$ & $\begin{array}{l}30.7 \\
30.9 \\
31.5 \\
33.3 \\
32.7 \\
35.3 \\
34.1 \\
33.1\end{array}$ & $\begin{array}{l}27.5^{\S \S} \\
25.0 \\
25.8 \\
27.3 \\
27.3 \\
29.1 \\
27.8 \\
26.9\end{array}$ & $\begin{array}{l}381 \\
405 \\
261 \\
351 \\
145 \\
170 \\
197 \\
735\end{array}$ & $\begin{array}{c}39^{\S \S} \\
61 \\
101 \\
181 \\
129 \\
81 \\
112 \\
170\end{array}$ & $\begin{array}{l}264 \\
355 \\
185 \\
? \\
145 \\
104 \\
124 \\
?\end{array}$ & $\begin{array}{l}\text { Outer } \\
\text { Outer } \\
\text { Inner } \\
\text { Outer } \\
\text { Inner } \\
\text { Outer } \\
\text { Inner } \\
\text { Outer }\end{array}$ & $\begin{array}{r}14 \\
30 \\
94 \\
0 \\
0 \\
0 \\
0 \\
0\end{array}$ & $\begin{array}{l}\text { None } \\
\text { None } \\
\text { None } \\
\text { None } \\
\text { None } \\
\text { None } \\
\text { None } \\
\text { None }\end{array}$ \\
\hline
\end{tabular}

Notes: $\dagger=$ time between core recovery and first opening of the PCS; $\S=$ time when core was removed from ice at $0^{\circ} \mathrm{C} . *=$ runs where the PCS was configured to collect a water sample only, no core was taken. \# = water core only, although in a sediment zone with hydrate. $\dagger \dagger=$ problem with rapid gas release on Core $164-997 \mathrm{~A}-25 \mathrm{P}$. $\S \S=$ core did not equilibrate at $0^{\circ} \mathrm{C}$. $\mathrm{Q}=$ questionable, insufficient available data; $\mathrm{CL}=$ chloride anomalies in pore water of surrounding APC/XCB cores; $\mathrm{CL} \neq=\mathrm{chloride}$ anomaly in PCS interstitial water; $\mathrm{R}$ $=$ enhanced well $\log$ resistivity across depth interval; $\mathrm{S}=$ hydrate specimens in surrounding APC/XCB cores. $-=$ no figure. ? = ice completely melted during experiment.

the plots are corrected for gauge offset (see Dickens et al., Chap. 43, this volume). Pressure axes on the plots are linear and range from 0 to $5 \mathrm{MPa}$. Although this scaling precludes placement of small incremental volumes at high pressure, the low-pressure region of interest at $0^{\circ} \mathrm{C}$ is emphasized (Fig. 3). Note that Kvenvolden et al. (1983) used logarithmic pressure axes for time-pressure plots of gas release experiments with the pressure core barrel (PCB).

All volume-pressure plots have two features in common (Fig. 4): a near-vertical line at low volume that represents a pronounced drop in pressure with minimal gas release, and a region where significant volumes of gas are released with decreasing pressure.

These two features of the volume-pressure plots can be represented by three parameters (Table 2). The "high-pressure volume" is the small quantity of gas released at high pressure. The "threshold pressure" is the pressure where significant volumes of gas are suddenly released from the PCS. The "total gas volume" is the total quantity of gas (including the high-pressure volume) collected from the PCS.

Gas analyses indicate that the high-pressure volume is composed of air. This air is presumably trapped inside of PCS mandrels and port connections as well as dissolved in borehole water before core recovery. This is why the seven PCS cores without sediment or methane still released a small quantity of gas as pressure was released over time. Values of high-pressure air listed in Table 2 range from 40 to $175 \mathrm{~mL}$. The reason for the wide range in high-pressure, air-volume estimates is unclear. However, accurate measurements of high-pressure air vol- umes with the current PCS manifold system are difficult because rates of gas release at high pressure cannot always be controlled.

Threshold pressures for the 22 PCS cores are listed in Table 2. These pressures are considered rough estimates for the same reason; high-pressure air volumes are poorly constrained. For some cores (e.g., Core 164-995A-45P), two threshold pressures are presented. The first threshold pressure is the pressure after the first aliquot of gas containing significant concentrations of $\mathrm{CH}_{4}$ was collected; the second threshold pressure is the pressure at which the first significant volume of gas was released from the PCS. The two pressures should be the same under ideal experimental conditions (see "Discussion" section). The existence of multiple threshold pressures may be related to different $\mathrm{CH}_{4}$ concentrations in the two chambers inside of the PCS at initial conditions (discussed below). All threshold pressures were below 4.5 MPa. Threshold pressures are somewhat proportional to total gas volumes (Table 2).

Total gas volumes reported in Table 2 are amounts of gas released from PCS cores after equilibration at 1 atm $(0.1 \mathrm{MPa})$ and $15^{\circ} \mathrm{C}$. These volumes range between $255 \mathrm{~mL}$ for Core 164-997A-33P and $8100 \mathrm{~mL}$ for Core 164-996D-7P. Total gas volumes for 14 of the 19 cores with volume-pressure plots are within 5\% uncertainty. Volumes reported for Cores 164-994C-70P, 164-995A-18P, 164-995A36P, 164-995A-48P and 164-995B-7P are minimum quantities (Table 2). The gas manifold system became clogged with sediment before atmospheric pressure could be achieved inside of the PCS for 
Table 2. Results from PCS gas-release experiments.

\begin{tabular}{|c|c|c|c|c|c|c|c|}
\hline Core & $\begin{array}{l}\text { High pressure } \\
\text { air volume } \\
(\mathrm{mL})\end{array}$ & $\begin{array}{l}\text { Threshold } \\
\text { pressures } \\
\text { (MPa) }\end{array}$ & $\begin{array}{l}\text { Total gas } \\
\text { volume } \\
(\mathrm{mL})\end{array}$ & $\begin{array}{c}\mathrm{CH}_{4} \\
\text { volume } \\
(\mathrm{mL})\end{array}$ & $\begin{array}{c}0^{\circ} \mathrm{C} \text { total gas } \\
\text { volume } \\
(\mathrm{mL})\end{array}$ & $\begin{array}{l}0^{\circ} \mathrm{C} \mathrm{CH}_{4} \\
\text { volume } \\
(\mathrm{mL})\end{array}$ & $\begin{array}{c}\text { Average } 0^{\circ} \mathrm{C} \\
\mathrm{CH}_{4} \text { release rate } \\
(\mathrm{mL} / \mathrm{min})\end{array}$ \\
\hline $\begin{array}{l}164-994 \mathrm{C}- \\
70 \mathrm{P}\end{array}$ & 120 & $1.9,1.1$ & $720(+1)$ & $600(+1)$ & $720(+2)$ & $600(+2)$ & 32 \\
\hline $\begin{array}{l}164-995 \mathrm{~A}- \\
0 \mathrm{P} * \\
18 \mathrm{P} \\
27 \mathrm{P} \\
36 \mathrm{P} \\
45 \mathrm{P} \\
48 \mathrm{P} \\
52 \mathrm{P}^{*} \\
52 \mathrm{P} \\
60 \mathrm{P} \\
70 \mathrm{P}\end{array}$ & $\begin{array}{r}140 \\
60 \\
105 \\
130 \\
175 \\
125 \\
85 \\
65 \\
70 \\
75\end{array}$ & $\begin{array}{l}<0.4 \\
\mathrm{NA} \\
3.9,1.5 \\
2.1,1.4 \\
4.4,1.1 \\
3.8,1.5 \\
\mathrm{NA} \\
2.0 \\
>0.2 \\
>0.1\end{array}$ & $\begin{array}{c}140(+1) \\
555(++3) \\
4215 \\
1430(+3) \\
4310 \\
860(+4) \\
85 \\
2365 \\
1310 \\
285\end{array}$ & $\begin{array}{c}0(+1) \\
495(++3) \\
4110 \\
1300(+3) \\
4135 \\
735(+4) \\
0 \\
2300 \\
1240 \\
210\end{array}$ & $\begin{array}{c}140(+2) \\
555(++3) \\
3975(++2) \\
1420(+2) \\
4140(+2) \\
690(+2,+4) \\
\text { No ice } \\
2225(+2) \\
1035(++2) \\
\text { No ice }\end{array}$ & $\begin{array}{c}0(+2) \\
495(++3) \\
3870(++2) \\
1290(+2) \\
3965(+2) \\
565(+2,+4) \\
\text { No ice } \\
2160(+2) \\
965(++2) \\
\text { No ice }\end{array}$ & $\begin{array}{c}0 \\
7 \\
17 \\
9 \\
60 \\
8 \\
\text { NA } \\
70 \\
22 \\
\text { NA }\end{array}$ \\
\hline $\begin{array}{l}164-995 \mathrm{~B}- \\
7 \mathrm{P} \\
10 \mathrm{P}\end{array}$ & $\begin{array}{r}80 \\
125\end{array}$ & $\begin{array}{c}1.9 \\
3.0,0.9\end{array}$ & $\begin{array}{c}2330(+1) \\
980\end{array}$ & $\begin{array}{c}2250(+1) \\
855\end{array}$ & $\begin{array}{l}2330(+2) \\
680(++2)\end{array}$ & $\begin{array}{l}2250(+2) \\
555(++2)\end{array}$ & $\begin{array}{r}15 \\
4\end{array}$ \\
\hline $\begin{array}{l}\text { 164-996A- } \\
7 \mathrm{P}\end{array}$ & 100 & 3.2 & 5415 & 5315 & $5030(++2)$ & $4930(++2)$ & 7 \\
\hline $\begin{array}{l}\text { 164-996D- } \\
7 \mathrm{P}\end{array}$ & 130 & 2.9 & 8100 & 7970 & $7810(++2)$ & $7680(++2)$ & 8 \\
\hline $\begin{array}{l}\text { 164-996E- } \\
8 \mathrm{P}\end{array}$ & 125 & NA & 575 & 450 & No ice & No ice & NA \\
\hline $\begin{array}{c}164-997 \mathrm{~A}- \\
18 \mathrm{P} \\
25 \mathrm{P} \\
33 \mathrm{P} \\
49 \mathrm{P} \\
55 \mathrm{P}\end{array}$ & $\begin{array}{r}175 \\
90 \\
115 \\
130 \\
145\end{array}$ & $\begin{array}{c}2.9,0.3 \\
\text { NA } \\
1.2,0.2 \\
3.3 \\
3.0\end{array}$ & $\begin{array}{c}450 \\
7485 \\
290 \\
7050 \\
6380\end{array}$ & $\begin{array}{c}275 ? \\
7395 \\
175 \\
6920 \\
6235\end{array}$ & $\begin{array}{c}270 \\
\text { Unknown (5) } \\
255 \\
6785(+2) \\
5600(++3)\end{array}$ & $\begin{array}{c}95 \\
\text { Unknown (5) } \\
130 \\
6655(+1) \\
5455(++3)\end{array}$ & $\begin{array}{c}1 \\
\text { High (5) } \\
2 \\
42 \\
43\end{array}$ \\
\hline $\begin{array}{c}164-997 \mathrm{~B}- \\
10 \mathrm{P} \\
15 \mathrm{P} \\
21 \mathrm{P} \\
29 \mathrm{P}^{*} \\
32 \mathrm{P} \\
36 \mathrm{P} \\
40 \mathrm{P} \\
44 \mathrm{P}\end{array}$ & $\begin{array}{c}130 \\
40 \\
170 \\
110 \\
70(+1) \\
120 \\
70 \\
80\end{array}$ & $\begin{array}{l}3.8(6) \\
1.2 \\
1.8 \\
0.1 \\
0.1 \\
0.3 \\
0.2 \\
0.2\end{array}$ & $\begin{array}{c}5125 \\
3190 \\
3455 \\
110 \\
70(+1) \\
120 \\
70 \\
80\end{array}$ & $\begin{array}{c}4995 \\
3150 \\
3285 \\
0 \\
0(+1) \\
0 \\
0 \\
0\end{array}$ & $\begin{array}{c}5035 \\
3080 \\
3115(++2) \\
110 \\
70(+2) \\
110(+2) \\
70 \\
80\end{array}$ & $\begin{array}{c}4905 \\
3040 \\
2945(++2) \\
0 \\
0(+2) \\
0(+2) \\
0 \\
0\end{array}$ & $\begin{array}{r}22 \\
10 \\
35 \\
0 \\
0 \\
0 \\
0 \\
0\end{array}$ \\
\hline
\end{tabular}

Notes: Threshold pressures are not accurate because release of small volumes of gas could not be controlled at high pressure. $(+)=$ potential small addition; $(++)=$ potential large addition; * = runs where the PCS was configured to collect a water sample only, no core was taken. NA = not applicable. (1) = PCS not warmed; minimum total gas volume; $(2)=$ PCS not maintained at $0^{\circ} \mathrm{C}, 0.1 \mathrm{MPa}$ for a long time; minimum volumes; $(3)=$ port clog; (4) = a small but unknown quantity of gas was lost from Core $164-995 \mathrm{~A}-48 \mathrm{P}$; $(5)=$ gas released from this core rapidly under warming conditions; $(6)=$ temperature greater than $0^{\circ} \mathrm{C}$ when core was first opened.

Cores 164-994C-70P and 164-995A-18P; the PCS was not warmed to $15^{\circ} \mathrm{C}$ after reaching $0.1 \mathrm{MPa}$ for Cores $164-995 \mathrm{~A}-36 \mathrm{P}$ and $164-$ 995B-7P; and a small but unknown quantity of gas escaped the bubbling chamber during gas-release experiments for Core 164-995A48P.

The composition of gas released below the threshold pressure is greater than $98.5 \% \mathrm{CH}_{4}$ (Paull, Matsumoto, Wallace, et al., 1996). Thus, the total gas volume is approximately equivalent to the total amount of $\mathrm{CH}_{4}$ released from the PCS less the high-pressure air volume (Table 2).

Amounts of total gas and $\mathrm{CH}_{4}$ released over the duration of an experiment exceed amounts released at $0^{\circ} \mathrm{C}$ while the PCS is in an ice bath. Warming of the PCS at $0.1 \mathrm{MPa}$ to $15^{\circ} \mathrm{C}$ releases additional quantities of gas because gas saturation at these pressures decreases with increasing temperature under isobaric conditions. The " $0{ }^{\circ} \mathrm{C}$ total volume" and " $0{ }^{\circ} \mathrm{C} \mathrm{CH}_{4}$ volume" columns in Table 2 list observed gas amounts released at $0^{\circ} \mathrm{C}$ and under isothermal conditions. However, almost all of these values are less than one would expect given total gas volumes (Table 2) and $\mathrm{CH}_{4}$ saturation curves (e.g., Duan et al., 1992). In other words, warming of the PCS from $0^{\circ}$ to $15^{\circ} \mathrm{C}$ releases more $\mathrm{CH}_{4}$ than the difference between the amount of $\mathrm{CH}_{4}$ that can be stored in solutions saturated with $\mathrm{CH}_{4}$ at $0^{\circ}$ and $15^{\circ} \mathrm{C}(\sim 80 \mathrm{~mL})$. Note that Cores 164-994C-70P, 164-995A-0P*, 164-995B-7P and 164997B-32P were not warmed.

Average rates of gas release between the first opening of the PCS at $0^{\circ} \mathrm{C}$ and high pressure and the last release of gas at $0^{\circ} \mathrm{C}$ and 0.1
MPa vary by over an order of magnitude from $1 \mathrm{~mL} / \mathrm{min}$ to $70 \mathrm{~mL} /$ min (Table 2). Gas release typically was slower for cores at Sites 996 and 997 than for cores at Sites 994 and 995.

\section{DISCUSSION}

\section{Overall Volume-Pressure Profiles}

Overall shapes of volume-pressure plots vary considerably (Fig. 4). Many of the differences between volume-pressure plots can be understood by considering individual PCS cores and varying experimental parameters. For example, the significant increase in pressure with no change in volume for Core 164-995B-10P (Fig. 4J) undoubtedly was caused by warming of the PCS for $300 \mathrm{~min}$ with the PCS valve closed (Dickens et al., Chap. 43, this volume). We have identified many of these experimental artifacts in Tables 1-4 and in the notes for Fig. 4.

However, despite all differences in experimental parameters for individual cores, there are two general profiles for volume-pressure plots. Most cores give a concave downwards volume-pressure plot as exemplified by Core 164-995A-45P (Fig. 4E). After a threshold pressure is surpassed, there is a large drop in pressure with a disproportionally small increase in $\mathrm{CH}_{4}$ volume. Subsequent drops in pressure then release greater volumes of $\mathrm{CH}_{4}$ per drop in pressure. The threshold pressure (or second threshold pressure) for these cores (Table 2) 
A

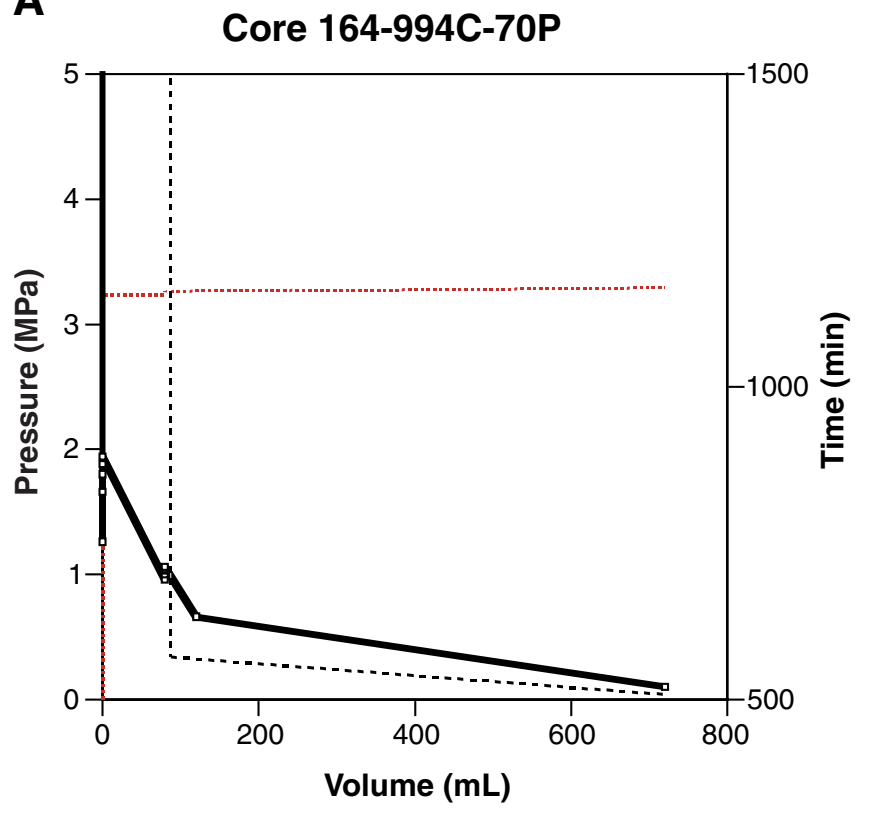

C

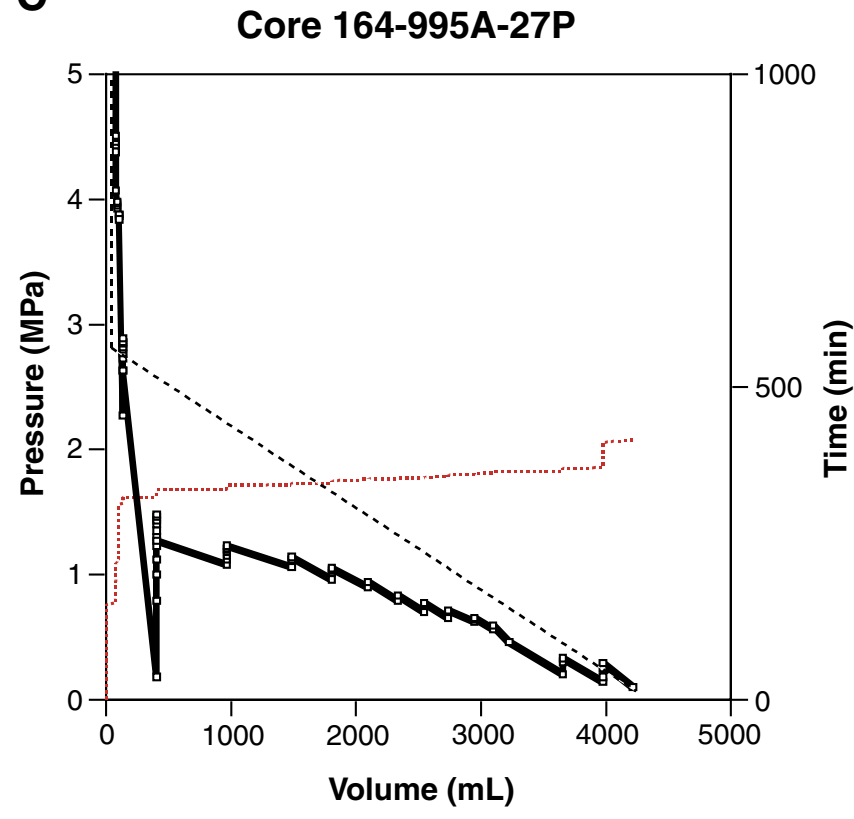

B

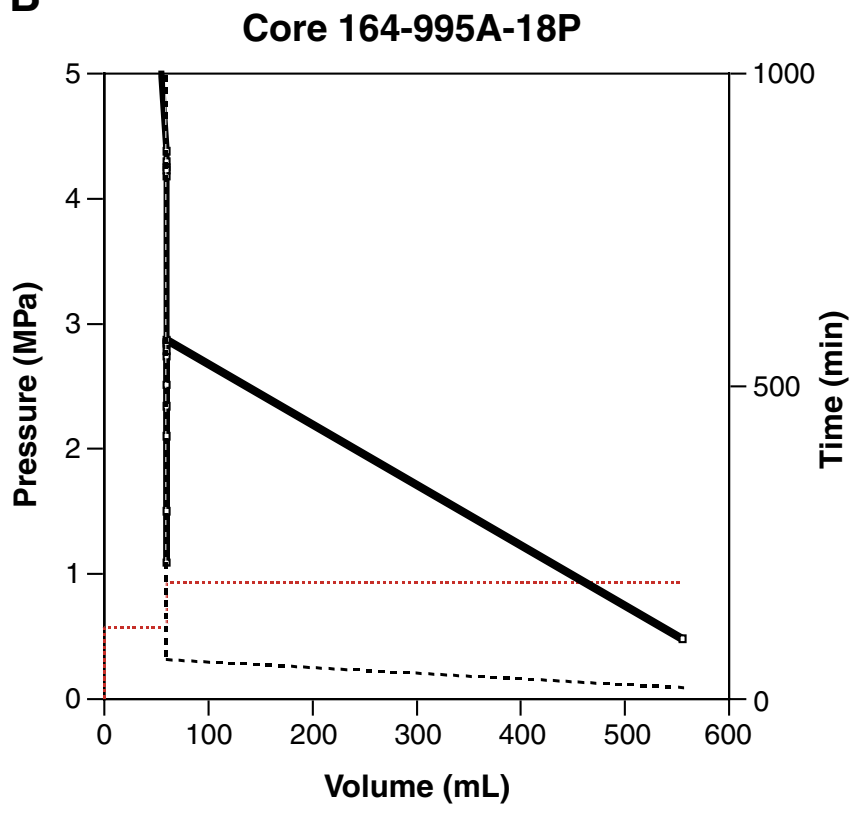

D

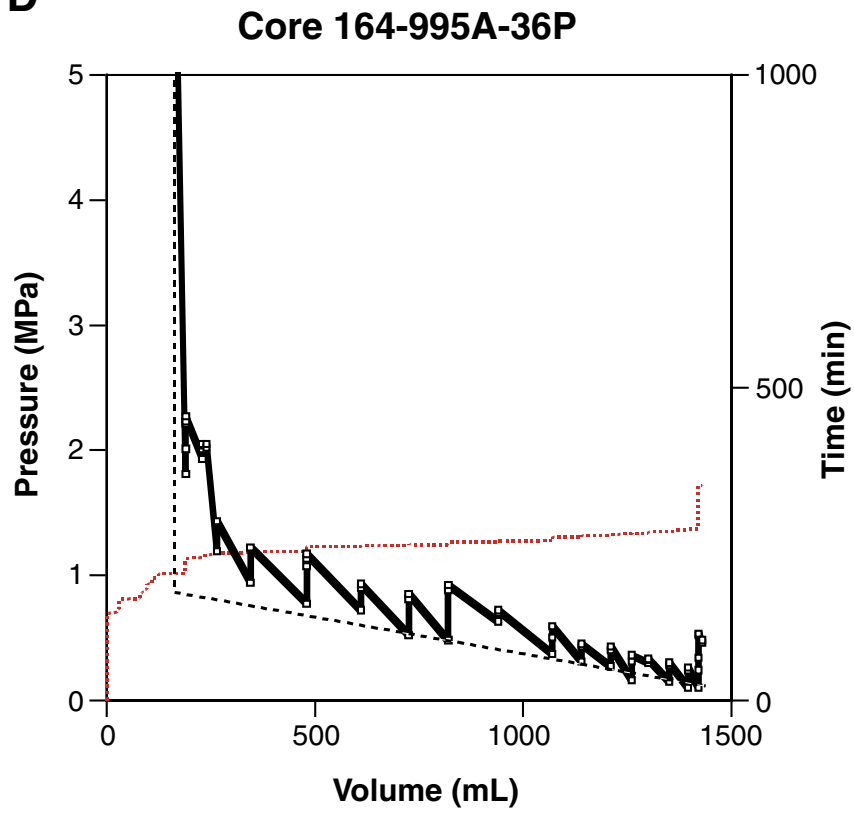

Figure 4. Observed (solid curve) and synthetic (dashed curve) volume-pressure plots for Cores (A) 164-994C-70P, (B) 164-995A-18P, (C) 164-995A-27P, (D) 164-995A-36P, (E) 164-995A-45P, (F) 164-995A-48P, (G) 164-995A-52P, (H) 164-995A-60P, (I) 164-995B-7P, (J) 164-995B-10P, (K) 164-996A-7P, (L) 164996D-7P, (M) 164-997A-18P, (N) 164-997A-25P, (O) 164-997A-33P, (P) 164-997A-49P, (Q) 164-997A-55P, (R) 164-997B-10P, (S) 164-997B-15P, and (T) 164997B-21P. Also shown are volume-time plots (stippled curve) for each core. Total volumes of gas released for each core are listed in Table 2. A. Core 164-994C$70 \mathrm{P}$ released $720 \mathrm{~mL}$ of gas $\left(\sim 600 \mathrm{~mL}\right.$ of $\left.\mathrm{CH}_{4}\right)$ at $0^{\circ} \mathrm{C}$ over $19 \mathrm{~min}$. Gas was released very quickly, and the core was not removed from the ice bath after reaching atmospheric pressure. B. Core 164-995A-18P released $555 \mathrm{~mL}$ of gas $\left(\sim 495 \mathrm{~mL}\right.$ of $\left.\mathrm{CH}_{4}\right)$ at $0^{\circ} \mathrm{C}$ over $76 \mathrm{~min}$. The port connection to this core became clogged with sediment prior to release of all gas at atmospheric pressure. Pressures on the synthetic volume-pressure plot for B are too low for a given volume. C. Core 164-995A-27P released $3975 \mathrm{~mL}$ of gas $\left(\sim 3870 \mathrm{~mL}\right.$ of $\left.\mathrm{CH}_{4}\right)$ at $0^{\circ} \mathrm{C}$ over $225 \mathrm{~min}$, and $4215 \mathrm{~mL}$ of gas $\left(\sim 410 \mathrm{~mL}\right.$ of $\left.\mathrm{CH}_{4}\right)$ at less than $\sim 15^{\circ} \mathrm{C}$ over $264 \mathrm{~min}$. D.

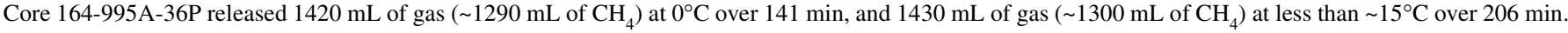
The port connection to this core became clogged with sediment during warming of the core (although after atmospheric pressure was reached initially). Pressures on the synthetic volume-pressure plot for D are too low for a given volume. (Continued on next page.) 
E

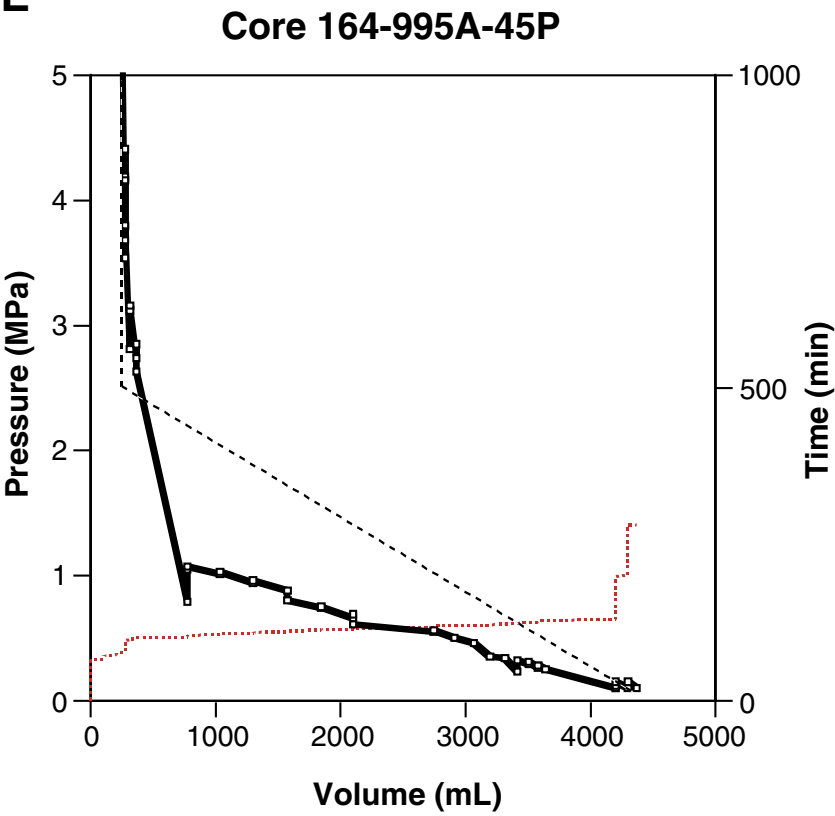

G

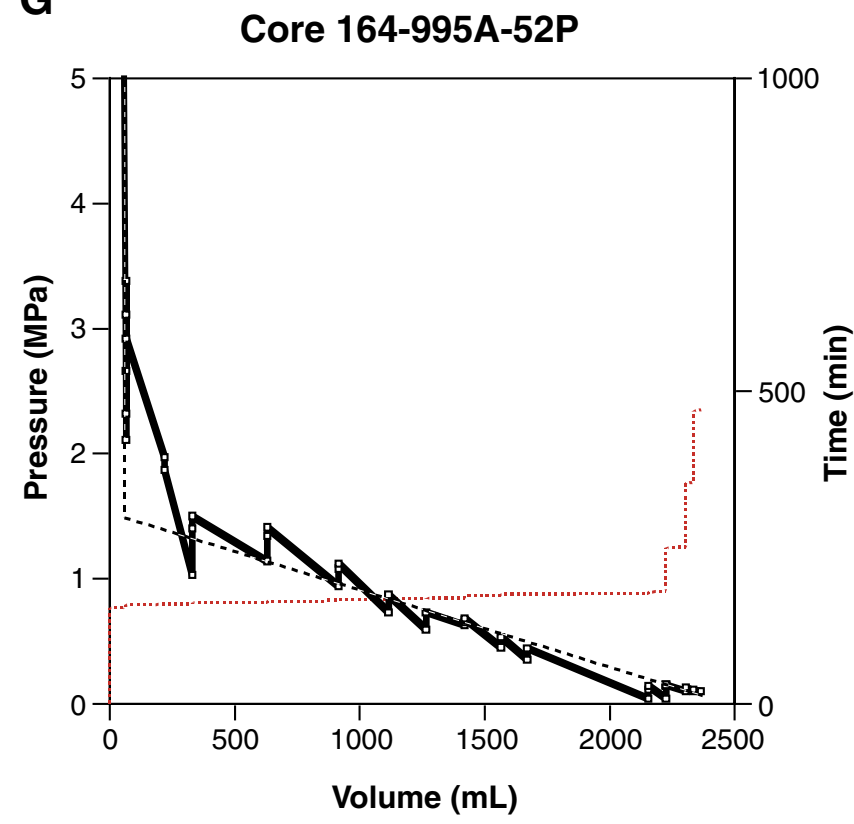

$\mathbf{F}$
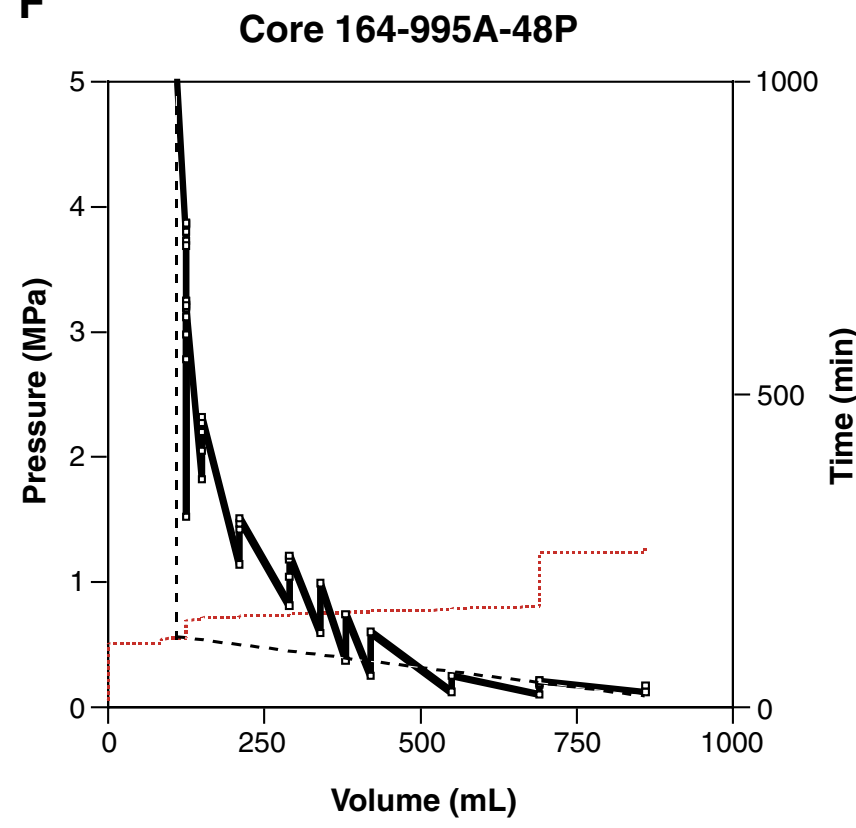

H

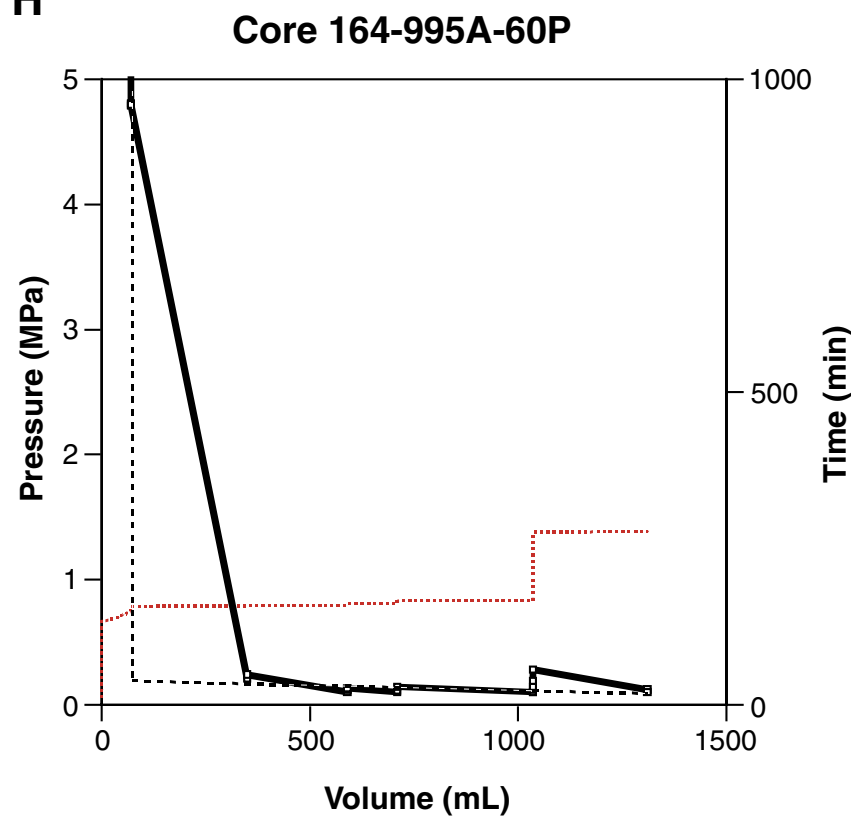

Figure 4 (continued). E. Core 164-995A-45P released $4200 \mathrm{~mL}$ of gas $\left(\sim 4025 \mathrm{~mL}\right.$ of $\left.\mathrm{CH}_{4}\right)$ at $0^{\circ} \mathrm{C}$ over $67 \mathrm{~min}$, and $4370 \mathrm{~mL}$ of gas $\left(\sim 4195 \mathrm{~mL}\right.$ of $\left.\mathrm{CH}_{4}\right)$ at less than $\sim 15^{\circ} \mathrm{C}$ over $216 \mathrm{~min}$. F. Core $164-995 \mathrm{~A}-48 \mathrm{P}$ released $815 \mathrm{~mL}$ of gas $\left(\sim 690 \mathrm{~mL}\right.$ of $\left.\mathrm{CH}_{4}\right)$ at $0^{\circ} \mathrm{C}$ over $67 \mathrm{~min}$, and $985 \mathrm{~mL}$ of gas $\left(\sim 860 \mathrm{~mL}\right.$ of $\left.\mathrm{CH}_{4}\right)$ at less than $\sim 15^{\circ} \mathrm{C}$ over $156 \mathrm{~min}$. An unknown volume of gas was lost from this core at a pressure between 1.52 and $3.69 \mathrm{MPa}$. Pressures on the synthetic volumepressure plot for $\mathrm{F}$ are too low for a given volume. G. Core 164-995A-52P released $2225 \mathrm{~mL}$ of gas $\left(2160 \mathrm{~mL}\right.$ of $\left.\mathrm{CH}_{4}\right)$ at $0^{\circ} \mathrm{C}$ over $31 \mathrm{~min}$, and $2365 \mathrm{~mL}$ of gas $\left(\sim 2300 \mathrm{~mL}\right.$ of $\left.\mathrm{CH}_{4}\right)$ at less than $\sim 15^{\circ} \mathrm{C}$ over $318 \mathrm{~min}$. H. Core $164-995 \mathrm{~A}-60 \mathrm{P}$ released $1035 \mathrm{~mL}$ of gas $\left(\sim 965 \mathrm{~mL}\right.$ of $\left.\mathrm{CH}_{4}\right)$ at $0^{\circ} \mathrm{C}$ over $44 \mathrm{~min}$, and $1310 \mathrm{~mL}$ of gas $\left(\sim 1260 \mathrm{~mL}\right.$ of $\left.\mathrm{CH}_{4}\right)$ at less than $\sim 15^{\circ} \mathrm{C}$ over a total time of $144 \mathrm{~min}$. (Continued on next page.)

is less than $2.9 \mathrm{MPa}$ - the pressure of the $\mathrm{CH}_{4}$ gas- $\mathrm{CH}_{4}$ hydrate-water equilibrium curve at $0^{\circ} \mathrm{C}$ (Fig. 2).

In contrast, Cores 164-996A-7P (Fig. 4K), 164-996D-7P (Fig. 4L), 164-997B-49P (Fig. 4P), 164-997A-55P (Fig. 4Q), and 164997B-10P (Fig. 4R) give volume-pressure plots with portions that are horizontal or concave upwards. In these cases, after the threshold pressure is surpassed, a small (or negligible) drop in pressure leads to a disproportionally large release of $\mathrm{CH}_{4}$ volume. The threshold pressure for these cores (Table 2) is at or above $2.9 \mathrm{MPa}$.
Based on these observations, we suggest the difference in overall volume-pressure profiles distinguishes PCS cores that contained only dissolved $\mathrm{CH}_{4}$ (e.g., 164-Cores 995A-45P and 164-995A-60P) from cores that contained $\mathrm{CH}_{4}$ hydrate and dissolved $\mathrm{CH}_{4}$ (Cores 164996A-7P, 164-996D-7P, 164-997B-49P, 164-997A-55P, and 164997B-10P). This suggestion is broadly consistent with the theory outlined by Hunt (1979) and Kvenvolden et al. (1983). However, we give a fundamental qualifier: our interpretation is for the start of experimental conditions when the PCS is placed in an ice bath and not 
I

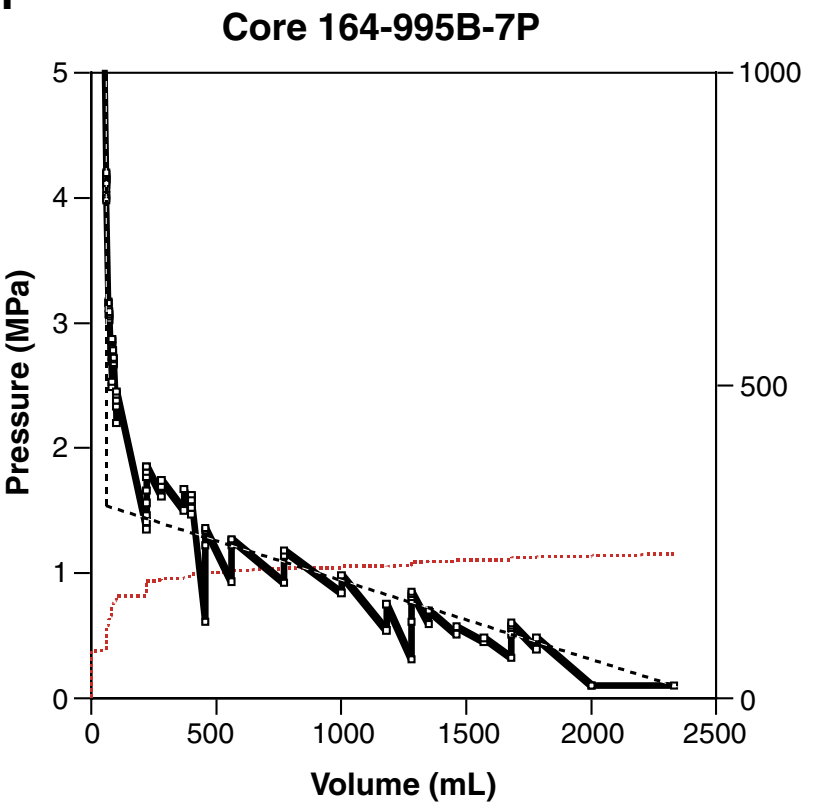

$\mathbf{K}$

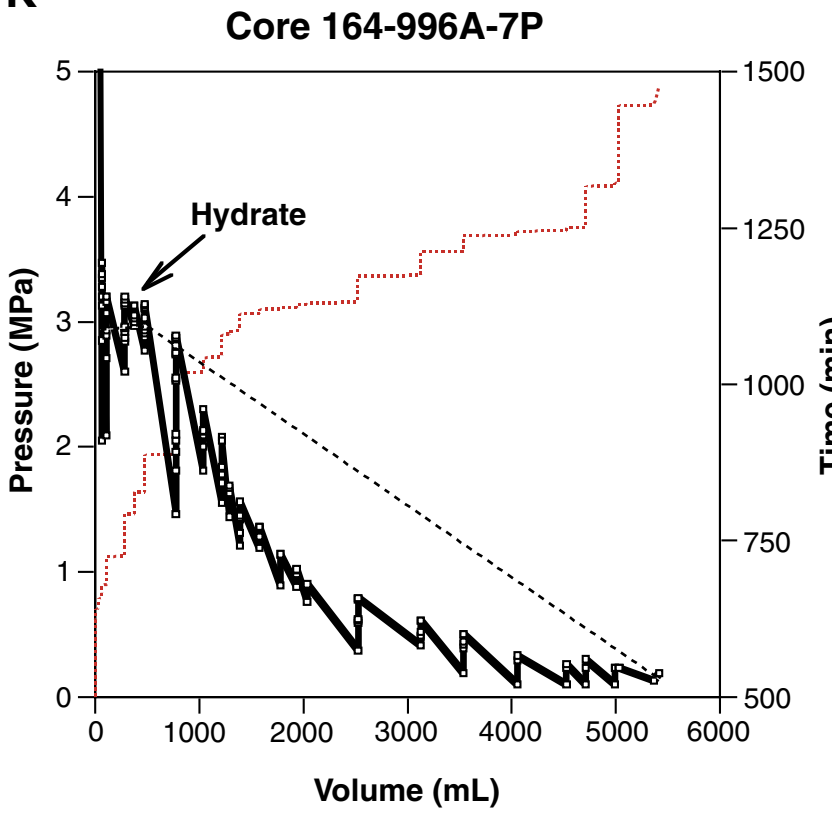

$\mathbf{J}$

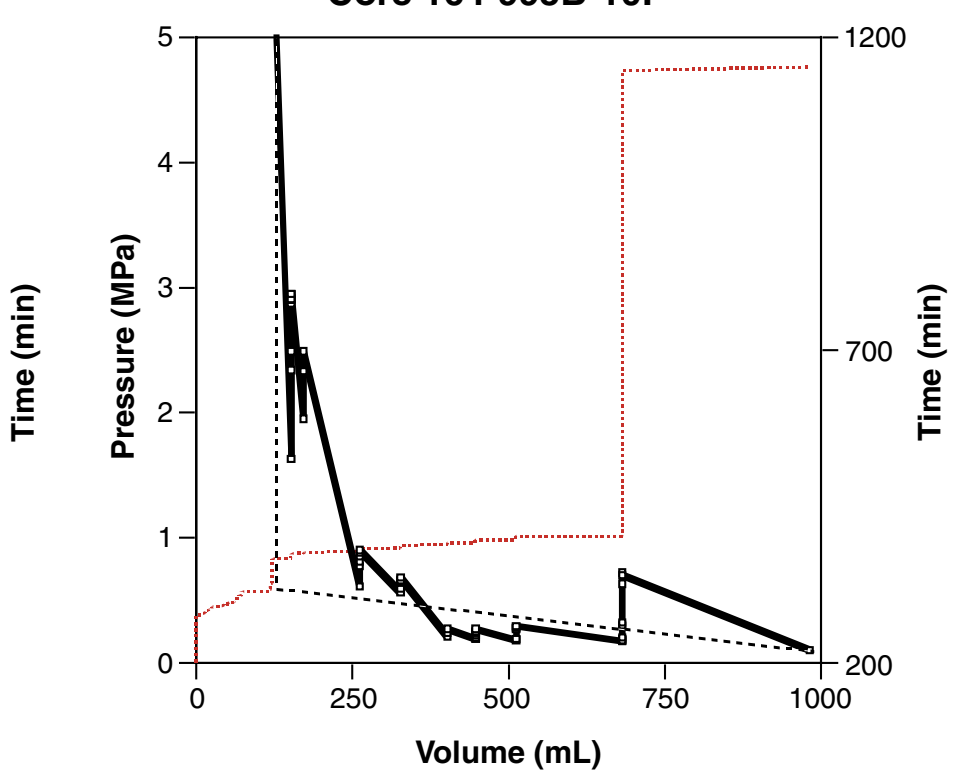

$\mathbf{L}$

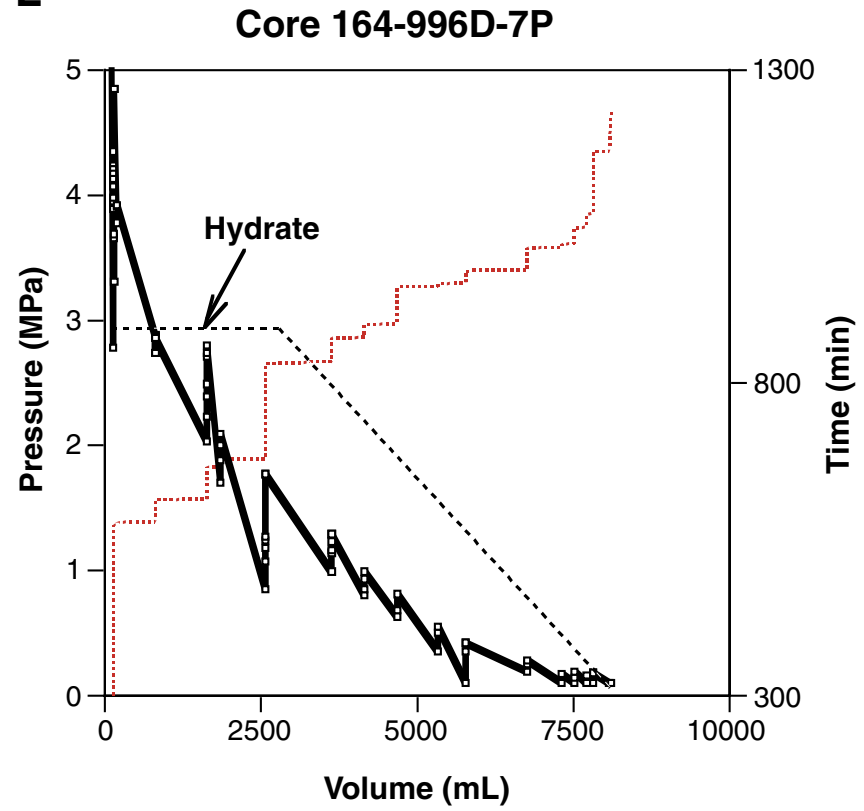

Figure 4 (continued). I. Core 164-995B-7P released $2330 \mathrm{~mL}$ of gas $\left(2250 \mathrm{~mL}\right.$ of $\left.\mathrm{CH}_{4}\right)$ at $0^{\circ} \mathrm{C}$ over $155 \mathrm{~min}$. The core was not removed from the ice bath after reaching atmospheric pressure. J. Core 164-995B-10P released $680 \mathrm{~mL}$ of gas $\left(\sim 555 \mathrm{~mL}\right.$ of $\left.\mathrm{CH}_{4}\right)$ at $0^{\circ} \mathrm{C}$ over $144 \mathrm{~min}$, and $980 \mathrm{~mL}$ of gas $\left(\sim 855 \mathrm{~mL}\right.$ of CH$\left.{ }_{4}\right)$ at less than $\sim 15^{\circ} \mathrm{C}$ over a total time of $877 \mathrm{~min}$. The rise in pressure at $1105 \mathrm{~mL}$ reflects long warming of this core after relatively rapid gas release in the early stages of the experiment. K. Core 164-996A-7P released $5030 \mathrm{~mL}$ of gas $\left(\sim 4930 \mathrm{~mL}\right.$ of $\left.\mathrm{CH}_{4}\right)$ at $0^{\circ} \mathrm{C}$ over $701 \mathrm{~min}$, and $5415 \mathrm{~mL}$ of gas $\left(\sim 5315 \mathrm{~mL}\right.$ of $\left.\mathrm{CH}_{4}\right)$ at less than $\sim 15^{\circ} \mathrm{C}$ over a total time of $852 \mathrm{~min}$. This core should have had $\mathrm{CH}_{4}$ hydrate even after equilibration of gas with borehole water in the outer chamber. L. Core 164-996D-7P released $7810 \mathrm{~mL}$ of gas $\left(\sim 7680 \mathrm{~mL}^{\circ} \mathrm{CH}_{4}\right)$ at $0^{\circ} \mathrm{C}$ over $974 \mathrm{~min}$, and $8100 \mathrm{~mL}$ of gas $\left(\sim 7970 \mathrm{~mL}^{\circ} \mathrm{CH}_{4}\right)$ at less than $\sim 15^{\circ} \mathrm{C}$ over a total time of $1136 \mathrm{~min}$. This core should have had $\mathrm{CH}_{4}$ hydrate even after equilibration of gas with borehole water in the outer chamber. (Continued next page.)

at in situ conditions in the sediment column, which is at temperatures from $3{ }^{\circ} \mathrm{C}$ at the sediment-water interface to greater than $25^{\circ} \mathrm{C}$ at depth (Paull, Matsumoto, Wallace, et al., 1996).

\section{Temperature and Borehole Water Problems}

The emphasis between experimental and in situ conditions can be understood by comparing observed and "expected" pressure-volume plots, and by considering how the PCS operates. Several PCS cores suspected of containing gas hydrate at in situ conditions (Table 1) do not give volume-pressure plots similar to expectations for cores with gas hydrate (e.g., Core 164-995A-45P; Fig. 4E). Moreover, Core 164-997B-10P rendered a volume-pressure plot somewhat similar to that expected for a core with gas hydrate (Fig. 4R), although there is no evidence that this core actually contained gas hydrate at in situ conditions (Table 1). 
M

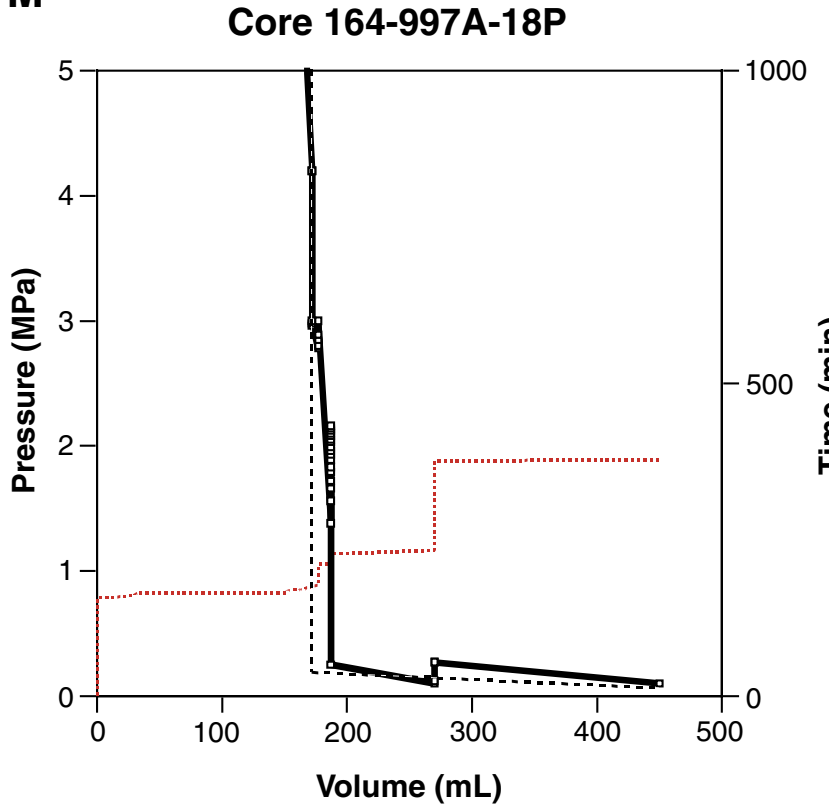

O

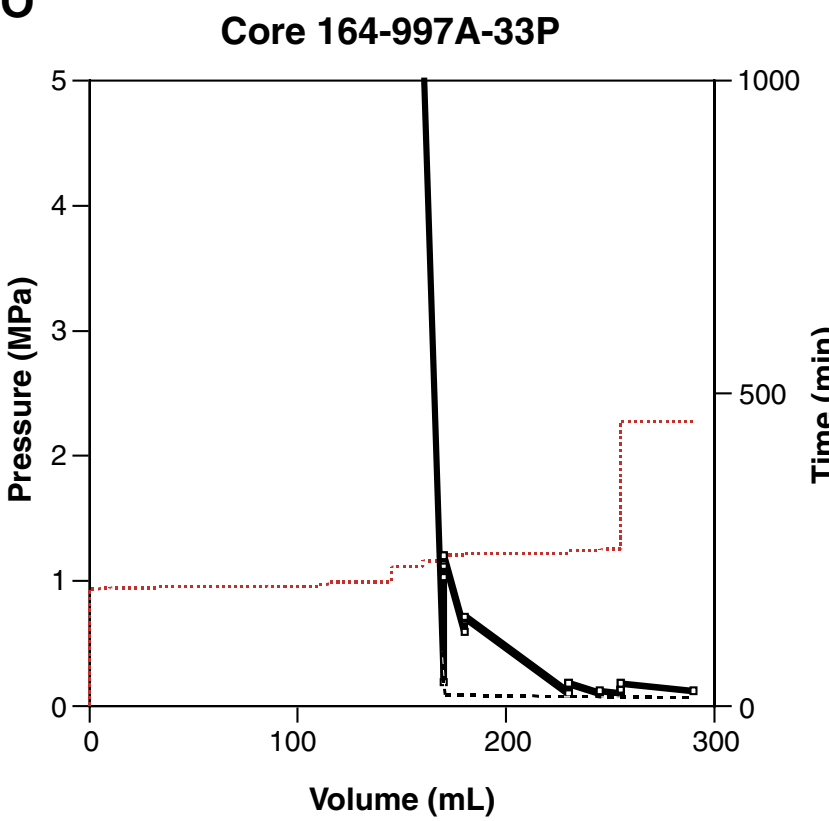

$\mathbf{N}$

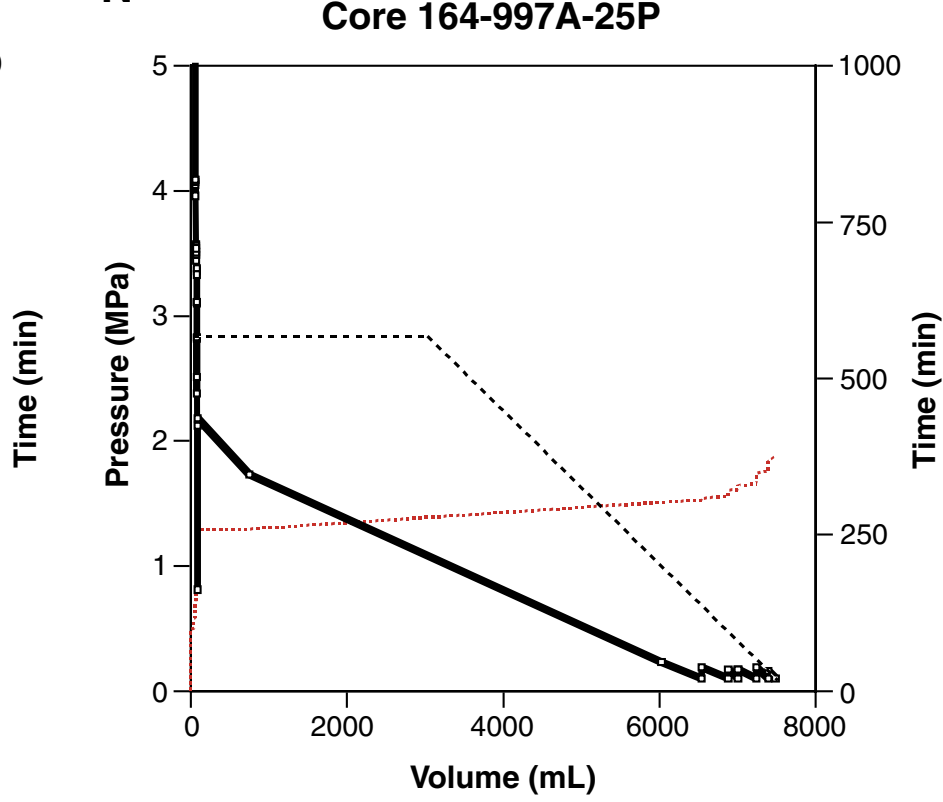

$\mathbf{P}$

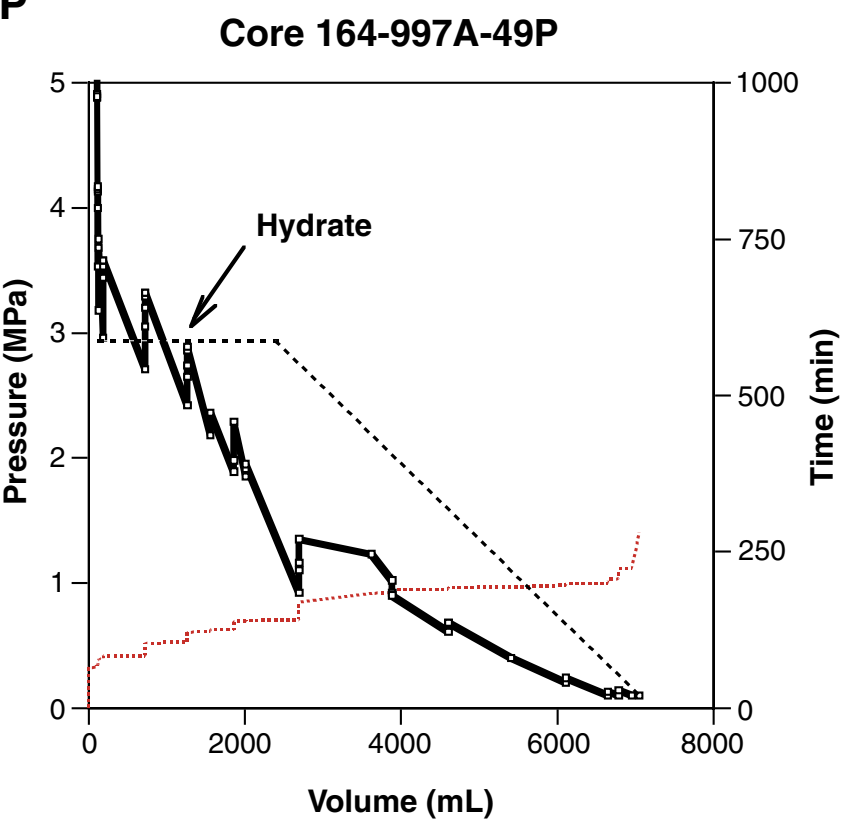

Figure 4 (continued). M. Core 164-997A-18P released $270 \mathrm{~mL}$ of gas $\left(\sim 95 \mathrm{~mL}\right.$ of $\left.\mathrm{CH}_{4}\right)$ at $0^{\circ} \mathrm{C}$ over $77 \mathrm{~min}$, and $450 \mathrm{~mL}$ of gas $\left(\sim 275 \mathrm{~mL}^{\circ} \mathrm{CH}_{4}\right)$ at less than $\sim 15^{\circ} \mathrm{C}$ over a total time of $1136 \mathrm{~min}$. N. Core $164-997 \mathrm{~A}-25 \mathrm{P}$ released $7485 \mathrm{~mL}$ of gas $\left(\sim 7395 \mathrm{~mL}\right.$ of $\left.\mathrm{CH}_{4}\right)$ at less than $\sim 15^{\circ} \mathrm{C}$ over a total time of $276 \mathrm{~min}$. Large quantities of gas $(>4 \mathrm{~L})$ were released from this core in several minutes (because the ice bath was needed elsewhere). At the start of degassing, this core should have had $\mathrm{CH}_{4}$ hydrate even after equilibration of gas with borehole water in the outer chamber. O. Core 164-997A-33P released 255 mL of gas $(\sim 130$

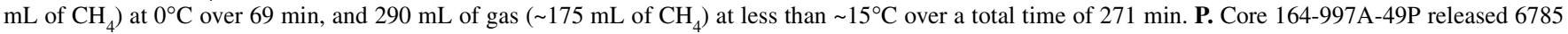
$\mathrm{mL}$ of gas $\left(\sim 6655 \mathrm{~mL}\right.$ of $\left.\mathrm{CH}_{4}\right)$ at $0^{\circ} \mathrm{C}$ over $158 \mathrm{~min}$, and $7050 \mathrm{~mL}$ of gas $\left(\sim 6920 \mathrm{~mL}\right.$ of $\left.\mathrm{CH}_{4}\right)$ at less than $\sim 15^{\circ} \mathrm{C}$ over a total time of $217 \mathrm{~min}$. This core should have had $\mathrm{CH}_{4}$ hydrate even after equilibration of gas with borehole water in the outer chamber. (Continued next page.)

The problem is twofold. First, in situ temperatures for PCS cores are significantly greater than $0^{\circ} \mathrm{C}$ because of the geotherm. Thus, there is the possibility that a core recovered with free $\mathrm{CH}_{4}$ gas and dissolved $\mathrm{CH}_{4}$ at in situ pressure and temperature conditions (i.e., no gas hydrate) could form $\mathrm{CH}_{4}$ hydrate upon cooling to $0^{\circ} \mathrm{C}$.

Second, the PCS contains two chambers and substantial quantities of borehole water. There is an inner chamber that contains a sediment core and borehole water to a total volume of $1385 \mathrm{~mL}$. There is also an outer chamber that contains $2615 \mathrm{~mL}$ of borehole water. Because the two chambers are connected inside of the PCS (Pettigrew, 1992), and because borehole water contains negligible quantities of $\mathrm{CH}_{4}$ (Paull, Matsumoto, Wallace, et al., 1996), a core recovered at high $\mathrm{CH}_{4}$ concentration at in situ conditions equilibrates with borehole water of low $\mathrm{CH}_{4}$ concentration before gas release experiments are initiated. The dilution resulting from this mixing is significant (at least $70 \%$ ). For example, a $1385-\mathrm{cm}^{3}$ core with $60 \%$ porosity and a 
Q

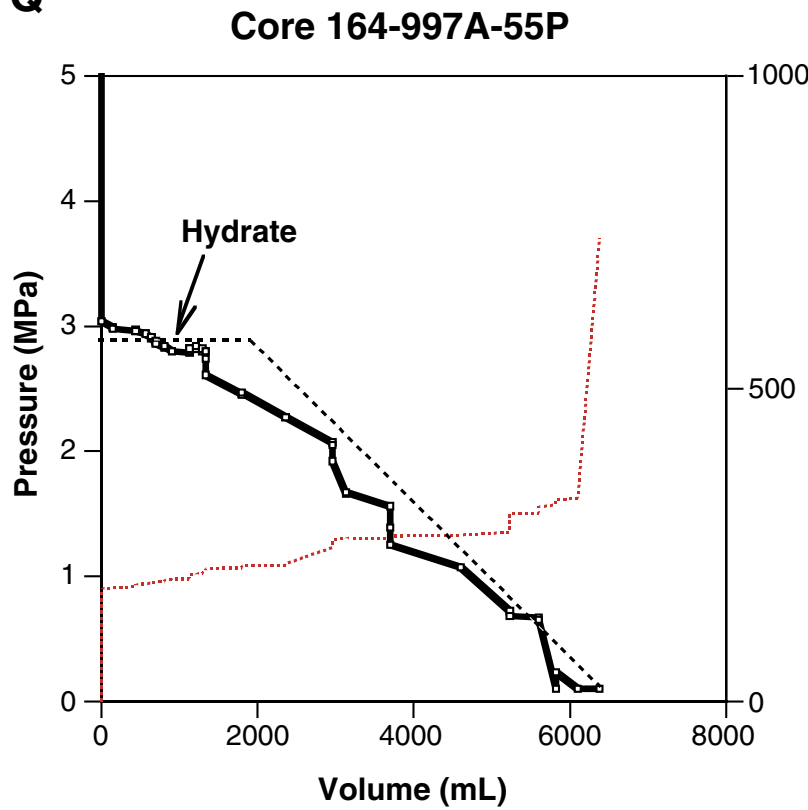

S

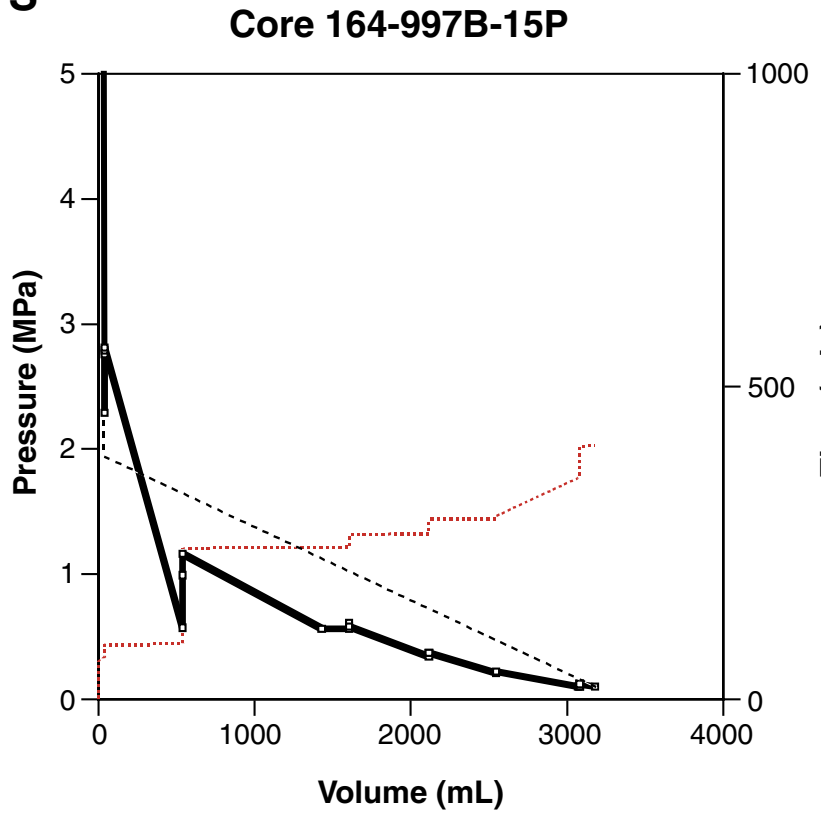

$\mathbf{R}$

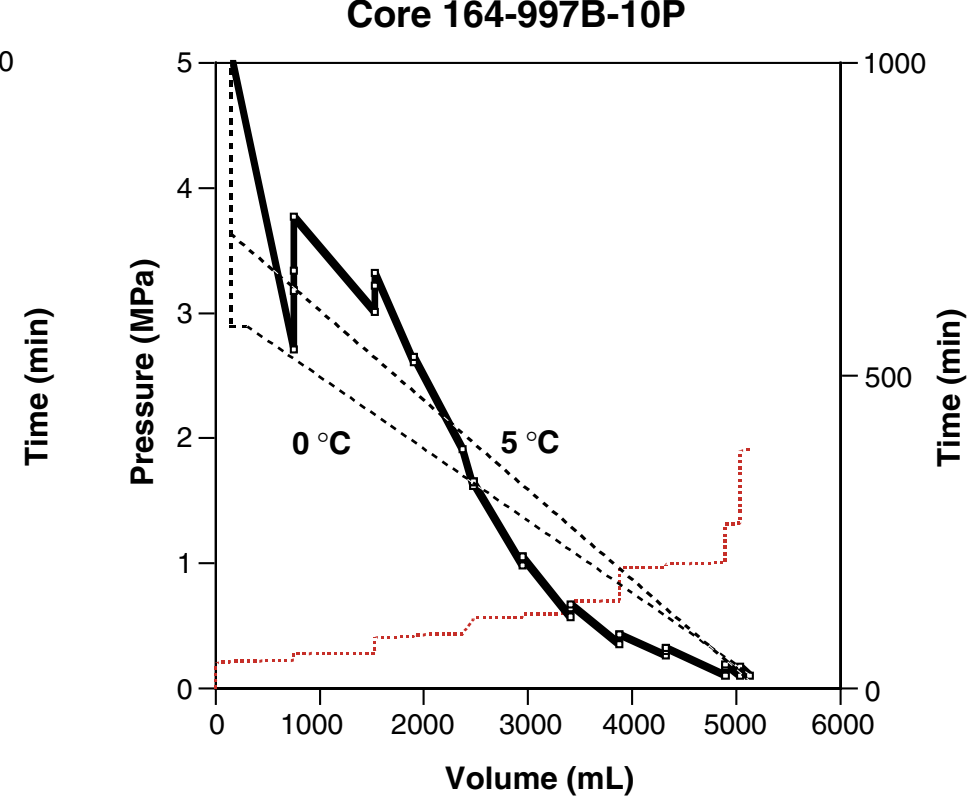

$\mathbf{T}$

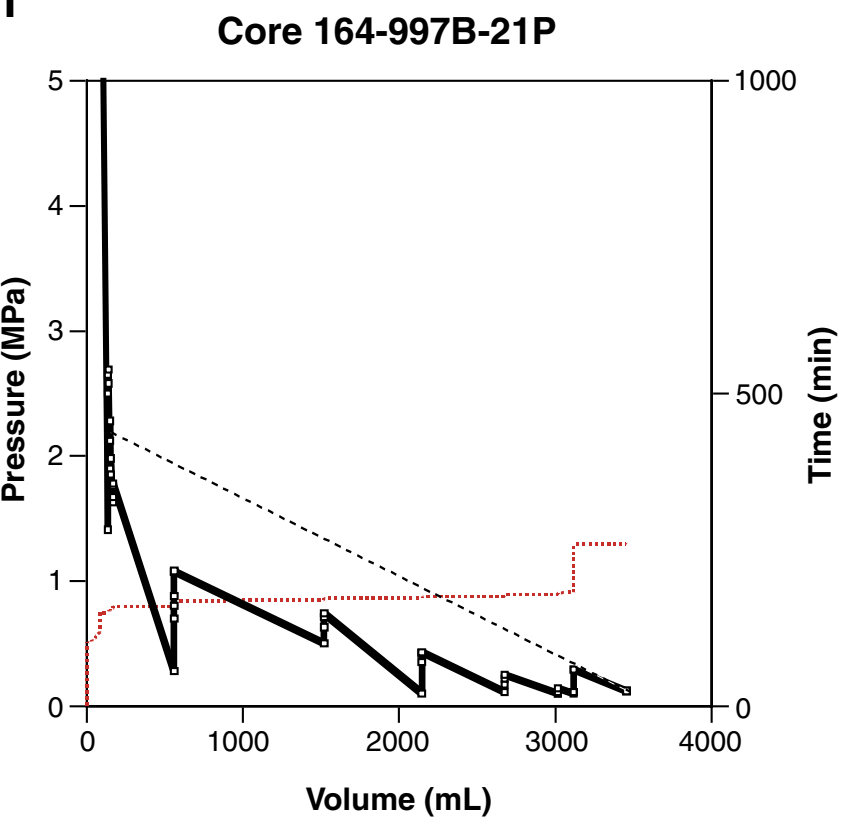

Figure 4 (continued). Q. Core 164-997A-55P released $5600 \mathrm{~mL}$ of gas $\left(\sim 5455 \mathrm{~mL}\right.$ of $\left.\mathrm{CH}_{4}\right)$ at $0^{\circ} \mathrm{C}$ over $126 \mathrm{~min}$, and $6380 \mathrm{~mL}$ of gas $\left(\sim 6235 \mathrm{~mL}\right.$ of $\left.\mathrm{CH}_{4}\right)$ at less than $\sim 15^{\circ} \mathrm{C}$ over a total time of $561 \mathrm{~min}$. This core should have had $\mathrm{CH}_{4}$ hydrate even after equilibration of gas with borehole water in the outer chamber. $\mathbf{R}$. Core 164-997B-10P released $5125 \mathrm{~mL}$ of gas $\left(\sim 4995 \mathrm{~mL}\right.$ of $\left.\mathrm{CH}_{4}\right)$ at less than $\sim 15^{\circ} \mathrm{C}$ over a total time of $342 \mathrm{~min}$. At $0^{\circ} \mathrm{C}$, this core should have had $\mathrm{CH}_{4}$ hydrate even after equilibration of gas with borehole water in the outer chamber. However, Core 164-995B-10P was not at $0^{\circ} \mathrm{C}$ when the first gas was released. Because expected volume-pressure relationships of gas release depend on temperature (Fig. 3), there are synthetic volume-pressure plots for $0^{\circ}$ and $5^{\circ} \mathrm{C}$. S. Core 164-997B-15P released $3080 \mathrm{~mL}$ of gas $\left(\sim 3040 \mathrm{~mL}\right.$ of $\left.\mathrm{CH}_{4}\right)$ at $0^{\circ} \mathrm{C}$ over $294 \mathrm{~min}$, and $3190 \mathrm{~mL}$ of gas $\left(\sim 3150 \mathrm{~mL}^{\circ} \mathrm{CH}_{4}\right)$ at less than $\sim 15^{\circ} \mathrm{C}$ over a total time of $344 \mathrm{~min}$. T. Core 164-997B-21P released $3115 \mathrm{~mL}$ of gas $\left(\sim 2945 \mathrm{~mL}^{\circ} \mathrm{CH}_{4}\right)$ at $0^{\circ} \mathrm{C}$ over $84 \mathrm{~min}$, and $3455 \mathrm{~mL}$ of gas $\left(\sim 3285 \mathrm{~mL}^{\circ} \mathrm{CH}_{4}\right)$ at less than $\sim 15^{\circ} \mathrm{C}$ over a total time of $160 \mathrm{~min}$.

$\mathrm{CH}_{4}$ molality of $0.20 \mathrm{~mol} / \mathrm{kg}$ at in situ conditions will have a $\mathrm{CH}_{4}$ molality of $0.05 \mathrm{~mol} / \mathrm{kg}$ before the first release of gas from the PCS if the core completely equilibrates with the large volume of $\mathrm{CH}_{4}$-poor borehole water that is present within the PCS (note that kilograms here and elsewhere refers to the entire $\mathrm{CH}_{4}$-water system, including solid hydrate but excluding sediment).

\section{Methane Concentrations}

At moderate temperature $\left(\mathrm{T}<\right.$ temperature on the $\mathrm{CH}_{4}$ gas $-\mathrm{CH}_{4}$ hydrate-water equilibrium curve) and high pressure ( $\mathrm{P}>$ pressure on the $\mathrm{CH}_{4}$ gas- $\mathrm{CH}_{4}$ hydrate-water equilibrium curve), the presence or absence of $\mathrm{CH}_{4}$ hydrate in a pressurized container will depend on 
Table 3. Water and gas information of PCS cores at Sites 994, 995, 996, and 997.

\begin{tabular}{|c|c|c|c|c|c|c|c|}
\hline Core & $\begin{array}{c}\text { Core } \\
\text { volume } \\
\left(\mathrm{cm}^{3}\right)^{\dagger}\end{array}$ & $\begin{array}{c}\text { Porosity } \\
(\%)^{\ddagger}\end{array}$ & $\begin{array}{c}\text { Pore } \\
\text { water mass } \\
(\mathrm{kg})^{\S}\end{array}$ & $\begin{array}{c}\text { Total } \\
\text { water mass } \\
(\mathrm{kg})^{\dagger \dagger}\end{array}$ & $\begin{array}{c}\text { Total } \mathrm{CH}_{4} \\
\text { amount } \\
(\mathrm{mol})^{\ddagger \ddagger}\end{array}$ & $\begin{array}{c}\text { Pore } \mathrm{CH}_{4} \\
\text { conc. } \\
(\mathrm{mol} / \mathrm{kg})^{\S \S}\end{array}$ & $\begin{array}{c}\text { Total } \mathrm{CH}_{4} \\
\text { conc. } \\
(\mathrm{mol} / \mathrm{kg})\end{array}$ \\
\hline $\begin{array}{l}\text { 164-994C- } \\
70 \mathrm{P}\end{array}$ & 277 & 58 & 0.17 & 4.00 & 0.03 & 0.15 & 0.01 \\
\hline $\begin{array}{c}164-995 \mathrm{~A}- \\
0 \mathrm{P}^{*} \\
18 \mathrm{P} \\
27 \mathrm{P} \\
36 \mathrm{P} \\
45 \mathrm{P} \\
48 \mathrm{P} \\
52 \mathrm{P}^{*} \\
52 \mathrm{P} \\
60 \mathrm{P} \\
70 \mathrm{P}\end{array}$ & $\begin{array}{r}0 \\
970 \\
1385 \\
1039 \\
804 \\
319 \\
0 \\
249 \\
125 \\
42\end{array}$ & $\begin{array}{r}0 \\
64 \\
60 \\
57 \\
56 \\
54 \\
0 \\
55 \\
55 \\
54\end{array}$ & $\begin{array}{l}0.00 \\
0.64 \\
0.86 \\
0.61 \\
0.46 \\
0.18 \\
0.00 \\
0.14 \\
0.07 \\
0.02\end{array}$ & $\begin{array}{l}4.12 \\
3.76 \\
3.55 \\
3.66 \\
3.76 \\
3.97 \\
4.12 \\
4.00 \\
4.06 \\
4.10\end{array}$ & $\begin{array}{l}0.00 \\
0.02 \\
0.17 \\
0.06 \\
0.18 \\
0.03 \\
0.00 \\
0.10 \\
0.05 \\
0.01\end{array}$ & $\begin{array}{l}\overline{-} \\
0.03 \\
0.20 \\
0.09 \\
0.38 \\
0.18 \\
\overline{0.69} \\
0.74 \\
0.38\end{array}$ & $\begin{array}{l}0.00 \\
0.01 \\
0.05 \\
0.02 \\
0.05 \\
0.01 \\
0.00 \\
0.02 \\
0.01 \\
0.00\end{array}$ \\
\hline $\begin{array}{l}\text { 164-995B- } \\
7 \mathrm{P} \\
10 \mathrm{P}\end{array}$ & $\begin{array}{r}1288 \\
901\end{array}$ & $\begin{array}{l}57 \\
56\end{array}$ & $\begin{array}{l}0.76 \\
0.52\end{array}$ & $\begin{array}{l}3.55 \\
3.71\end{array}$ & $\begin{array}{l}0.10 \\
0.04\end{array}$ & $\begin{array}{l}\text { 0.13 } \\
0.07\end{array}$ & $\begin{array}{l}0.03 \\
0.01\end{array}$ \\
\hline $\begin{array}{l}\text { 164-996A- } \\
7 \mathrm{P}\end{array}$ & 277 & 55 & 0.16 & 3.99 & 0.22 & 1.43 & 0.06 \\
\hline $\begin{array}{l}\text { 164-996D- } \\
7 \mathrm{P}\end{array}$ & 0 & 0 & 0.00 & 4.12 & 0.34 & - & 0.08 \\
\hline $\begin{array}{l}\text { 164-996E- } \\
8 \mathrm{P}\end{array}$ & 0 & 0 & 0.00 & 4.12 & 0.02 & - & 0.00 \\
\hline $\begin{array}{c}164-997 \mathrm{~A}- \\
18 \mathrm{P} \\
25 \mathrm{P} \\
33 \mathrm{P} \\
49 \mathrm{P} \\
55 \mathrm{P}\end{array}$ & $\begin{array}{r}582 \\
1219 \\
0 \\
887 \\
693\end{array}$ & $\begin{array}{r}63 \\
61 \\
0 \\
55 \\
56\end{array}$ & $\begin{array}{l}0.38 \\
0.77 \\
0.00 \\
0.50 \\
0.40\end{array}$ & $\begin{array}{l}3.90 \\
3.63 \\
4.12 \\
3.71 \\
3.81\end{array}$ & $\begin{array}{l}0.01 \\
0.31 \\
0.01 \\
0.29 \\
0.26\end{array}$ & $\begin{array}{l}0.03 \\
0.41 \\
\overline{0.58} \\
0.66\end{array}$ & $\begin{array}{l}0.00 \\
0.09 \\
0.00 \\
\mathbf{0 . 0 8} \\
\mathbf{0 . 0 7}\end{array}$ \\
\hline $\begin{array}{c}164-997 \mathrm{~B}- \\
10 \mathrm{P} \\
15 \mathrm{P} \\
21 \mathrm{P} \\
29 \mathrm{P}^{*} \\
32 \mathrm{P} \\
36 \mathrm{P} \\
40 \mathrm{P} \\
44 \mathrm{P}\end{array}$ & $\begin{array}{r}194 \\
416 \\
1302 \\
0 \\
0 \\
0 \\
0 \\
0\end{array}$ & $\begin{array}{r}56 \\
58 \\
52 \\
0 \\
0 \\
0 \\
0 \\
0\end{array}$ & $\begin{array}{l}0.11 \\
0.25 \\
0.70 \\
0.00 \\
0.00 \\
0.00 \\
0.00 \\
0.00\end{array}$ & $\begin{array}{l}4.03 \\
3.94 \\
3.48 \\
4.12 \\
4.12 \\
4.12 \\
4.12 \\
4.12\end{array}$ & $\begin{array}{l}0.21 \\
0.13 \\
0.14 \\
0 \\
0 \\
0 \\
0 \\
0\end{array}$ & $\begin{array}{l}1.89 \\
0.54 \\
0.20 \\
- \\
- \\
- \\
-\end{array}$ & $\begin{array}{l}\mathbf{0 . 0 5} \\
0.03 \\
0.04 \\
0.00 \\
0.00 \\
0.00 \\
0.00 \\
0.00\end{array}$ \\
\hline
\end{tabular}

Notes: $\dagger=\left(\right.$ core length $\times$ pi $\left.\times 2.1 \mathrm{~cm}^{2}\right) . \ddagger=$ average porosity from Paull, Matsumoto, Wallace, et al. $(1996) . \S=$ (pore volume $\times$ density of seawater). $\dagger \dagger=[$ total mass $=$ borehole volume $(4 \mathrm{~L})$ - sediment volume $\times$ density of seawater], where sediment volume $=\left(\right.$ core volume - pore volume); $+\neq=$ ideal gas law at $15^{\circ} \mathrm{C}$ and 1 atm, with volumes as in Table $2 . \S \S$ $=$ assumes all methane from sediment core. Boldface values are from samples that should have hydrate at $0^{\circ} \mathrm{C}$, although not necessarily at in situ conditions. $-=$ not calculated. $*$ = runs where the PCS was configured to collect a water sample only, no core was taken.

$\mathrm{CH}_{4}$ concentration (Fig. 2). The theoretical concentration necessary to form hydrate in seawater at $0^{\circ} \mathrm{C}$ is $0.052 \mathrm{~mol} / \mathrm{kg}$ (Handa, 1990).

Methane concentration can be calculated from the amount of $\mathrm{CH}_{4}$ released from the container and the mass of the water inside of the container. We have made two calculations for $\mathrm{CH}_{4}$ concentration (Table 3). The first calculation is the pore-space $\mathrm{CH}_{4}$ concentration. This is the $\mathrm{CH}_{4}$ concentration in the sediment core prior to equilibration with surrounding borehole water. In making this calculation, we have used shipboard values for porosity and have assumed that all $\mathrm{CH}_{4}$ released from the PCS was originally in pore space. The latter assumption is consistent with the fact that most PCS cores did not release $\mathrm{CH}_{4}$ unless they contained sediment (Tables 1-3). The second calculation is the total $\mathrm{CH}_{4}$ concentration. This is the $\mathrm{CH}_{4}$ concentration in the PCS after equilibration with surrounding borehole water, calculated assuming that there is $4000-\mathrm{cm}^{3}$ total volume (borehole water, sediment, and pore space) inside of the PCS.

All but two cores had sufficient quantities of $\mathrm{CH}_{4}$ to form $\mathrm{CH}_{4}$ hydrate in pore water at $0^{\circ} \mathrm{C}$ and pressure greater than $2.9 \mathrm{MPa}$ (Table 3 ). However, only six cores had sufficient quantities of $\mathrm{CH}_{4}$ to form $\mathrm{CH}_{4}$ hydrate in the PCS at $0^{\circ} \mathrm{C}$ and pressure greater than $2.9 \mathrm{MPa}$ after equilibration with borehole water (Table 3 ). Five of these six cores are those that gave volume-pressure plots interpreted as representing cores with $\mathrm{CH}_{4}$ hydrate. Volumes and pressures were released exceptionally fast from Core 164-997A-25P, and the volume-pressure plot for this particular core (Fig. 4N) cannot be used to make any interpretations regarding the presence or absence of $\mathrm{CH}_{4}$ hydrate.
Results of the first calculation-pore-space $\mathrm{CH}_{4}$ concentration (Table 3)-are of considerable interest and discussed elsewhere (Dickens et al., 1997). Pore-space $\mathrm{CH}_{4}$ concentrations are total $\mathrm{CH}_{4}$ amounts in pore space before borehole water dilution and release of pressure. Thus, these data represent in situ methane concentrations and can be used in conjunction with appropriate stability curves (Handa, 1990; Duan et al., 1992; Dickens and Quinby-Hunt, 1994, 1997; Tohidi et al., 1995) to estimate in situ quantities of gas hydrate and free gas (Dickens et al., 1997).

\section{Synthetic Volume-Pressure Plots}

As gas is slowly released from a pressurized core under isothermal conditions, expected changes in concentration and pressure (i.e., the "path" of the core in concentration-pressure space) are entirely dictated by the initial gas concentration (Fig. 2). A "synthetic" volumepressure plot, therefore, can be made for a pressurized core if the $\mathrm{CH}_{4}$ concentration and water mass are known, and if it is assumed that complete equilibrium is maintained at all times during degassing (i.e., gas is removed reversibly in an infinite number of steps).

Table 4 lists the expected threshold pressure, $\mathrm{CH}_{4}$ hydrate volume, and dissolved $\mathrm{CH}_{4}$ volume for all $29 \mathrm{PCS}$ cores at $0^{\circ} \mathrm{C}$ and $5^{\circ} \mathrm{C}$ given the calculated $\mathrm{CH}_{4}$ concentration and water mass for each core. Using this information, we have superimposed synthetic volumepressure plots on observed volume-pressure curves for 20 of the PCS cores (Fig. 4). 
Table 4. Predicted volume-pressure PCS information at Sites 994, 995, 996, and 997.

\begin{tabular}{|c|c|c|c|c|c|c|c|c|}
\hline Core & $\begin{array}{c}\text { Total } \\
\text { water } \\
\text { mass } \\
(\mathrm{kg})\end{array}$ & $\begin{array}{c}\text { Total } \\
\mathrm{CH}_{4} \\
\text { conc. } \\
\text { (mol/kg) }\end{array}$ & $\begin{array}{c}0^{\circ} \mathrm{C} \\
\text { threshold } \\
\mathrm{P} \text { estimate } \\
(\mathrm{MPa})\end{array}$ & $\begin{array}{c}0^{\circ} \mathrm{C} \\
\text { hydrate } \\
\text { volume } \\
(\mathrm{mL})\end{array}$ & $\begin{array}{c}0^{\circ} \mathrm{C} \\
\text { hydrate } \\
\text { volume } \\
(\mathrm{mL})\end{array}$ & $\begin{array}{c}5^{\circ} \mathrm{C} \\
\text { threshold } \\
\text { P estimate } \\
(\mathrm{MPa})\end{array}$ & $\begin{array}{c}5^{\circ} \mathrm{C} \\
\text { hydrate } \\
\text { volume } \\
(\mathrm{mL})\end{array}$ & $\begin{array}{c}5^{\circ} \mathrm{C} \\
\text { hydrate } \\
\text { volume } \\
(\mathrm{mL})\end{array}$ \\
\hline $\begin{array}{l}164-994 \mathrm{C}- \\
70 \mathrm{P}\end{array}$ & 4.00 & 0.01 & 0.35 & 0 & 600 & 0.44 & 0 & 600 \\
\hline $\begin{array}{l}164-995 \mathrm{~A}- \\
0 \mathrm{P}^{*} \\
18 \mathrm{P} \\
27 \mathrm{P} \\
36 \mathrm{P} \\
45 \mathrm{P} \\
48 \mathrm{P} \\
52 \mathrm{P}^{*} \\
52 \mathrm{P} \\
60 \mathrm{P} \\
70 \mathrm{P}\end{array}$ & $\begin{array}{l}4.12 \\
3.76 \\
3.55 \\
3.66 \\
3.76 \\
3.97 \\
4.12 \\
4.00 \\
4.06 \\
4.10\end{array}$ & $\begin{array}{l}0.00 \\
0.01 \\
0.05 \\
0.02 \\
0.05 \\
0.01 \\
0.00 \\
0.02 \\
0.01 \\
0.00\end{array}$ & $\begin{array}{l}0.00 \\
0.31 \\
2.73 \\
0.84 \\
2.53 \\
0.44 \\
0.00 \\
1.35 \\
0.73 \\
0.12\end{array}$ & $\begin{array}{l}0 \\
0 \\
0 \\
0 \\
0 \\
0 \\
0 \\
0 \\
0 \\
0\end{array}$ & $\begin{array}{r}0 \\
495 \\
4110 \\
1300 \\
4035 \\
735 \\
0 \\
2300 \\
1260 \\
210\end{array}$ & $\begin{array}{l}0.00 \\
0.38 \\
3.36 \\
1.03 \\
3.12 \\
0.63 \\
0.00 \\
1.67 \\
0.90 \\
0.15\end{array}$ & $\begin{array}{l}0 \\
0 \\
0 \\
0 \\
0 \\
0 \\
0 \\
0 \\
0 \\
0\end{array}$ & $\begin{array}{r}0 \\
495 \\
4110 \\
1300 \\
4035 \\
735 \\
0 \\
2300 \\
1260 \\
210\end{array}$ \\
\hline $\begin{array}{c}164-995 \mathrm{~B}- \\
7 \mathrm{P} \\
10 \mathrm{P}\end{array}$ & $\begin{array}{l}3.55 \\
3.71\end{array}$ & $\begin{array}{l}0.03 \\
0.01\end{array}$ & $\begin{array}{l}1.50 \\
0.54\end{array}$ & $\begin{array}{l}0 \\
0\end{array}$ & $\begin{array}{r}2250 \\
855\end{array}$ & $\begin{array}{l}1.84 \\
0.67\end{array}$ & $\begin{array}{l}0 \\
0\end{array}$ & $\begin{array}{r}2250 \\
855\end{array}$ \\
\hline $\begin{array}{l}\text { 164-996A- } \\
7 \mathrm{P}\end{array}$ & 3.99 & 0.06 & 2.90 & 417 & 4898 & 3.87 & 0 & 5315 \\
\hline $\begin{array}{l}\text { 164-996D- } \\
7 \mathrm{P}\end{array}$ & 4.12 & 0.08 & 2.90 & 2914 & 5056 & 4.95 & 946 & 7024 \\
\hline $\begin{array}{l}\text { 164-996E- } \\
8 \mathrm{P}\end{array}$ & 4.12 & 0.00 & 0.26 & 0 & 450 & 0.32 & 0 & 450 \\
\hline $\begin{array}{c}164-997 \mathrm{~A}- \\
18 \mathrm{P} \\
25 \mathrm{P} \\
33 \mathrm{P} \\
49 \mathrm{P} \\
55 \mathrm{P}\end{array}$ & $\begin{array}{l}3.90 \\
3.63 \\
4.12 \\
3.71 \\
3.81\end{array}$ & $\begin{array}{l}0.00 \\
0.09 \\
0.00 \\
0.08 \\
0.07\end{array}$ & $\begin{array}{l}0.17 \\
2.90 \\
0.00 \\
2.90 \\
2.90\end{array}$ & $\begin{array}{r}0 \\
2940 \\
0 \\
2368 \\
1564\end{array}$ & $\begin{array}{r}275 \\
4455 \\
175 \\
4552 \\
4671\end{array}$ & $\begin{array}{l}0.20 \\
4.95 \\
0.00 \\
4.95 \\
4.76\end{array}$ & $\begin{array}{r}0 \\
1206 \\
0 \\
597 \\
0\end{array}$ & $\begin{array}{r}275 \\
6189 \\
175 \\
6323 \\
6235\end{array}$ \\
\hline $\begin{array}{c}164-997 \mathrm{~B}- \\
10 \mathrm{P} \\
15 \mathrm{P} \\
21 \mathrm{P} \\
29 \mathrm{P} * \\
32 \mathrm{P} \\
36 \mathrm{P} \\
40 \mathrm{P} \\
44 \mathrm{P}\end{array}$ & $\begin{array}{l}4.03 \\
3.94 \\
3.48 \\
4.12 \\
4.12 \\
4.12 \\
4.12 \\
4.12\end{array}$ & $\begin{array}{l}0.05 \\
0.03 \\
0.04 \\
0.00 \\
0.00 \\
0.00 \\
0.00 \\
0.00\end{array}$ & $\begin{array}{l}2.90 \\
1.89 \\
2.23 \\
0.00 \\
0.00 \\
0.00 \\
0.00 \\
0.00\end{array}$ & $\begin{array}{r}47 \\
0 \\
0 \\
0 \\
0 \\
0 \\
0 \\
0\end{array}$ & $\begin{array}{r}4948 \\
3150 \\
3285 \\
0 \\
0 \\
0 \\
0 \\
0\end{array}$ & $\begin{array}{l}3.60 \\
2.32 \\
2.74 \\
0.00 \\
0.00 \\
0.00 \\
0.00 \\
0.00\end{array}$ & $\begin{array}{l}0 \\
0 \\
0 \\
0 \\
0 \\
0 \\
0 \\
0\end{array}$ & $\begin{array}{r}4995 \\
3150 \\
3285 \\
0 \\
0 \\
0 \\
0 \\
0\end{array}$ \\
\hline
\end{tabular}

Notes: Calculations assume $\mathrm{CH}_{4}$ in core is in equilibrium with surrounding borehole water. Calculations also assume all $\mathrm{CH}_{4}$ was released at $0^{\circ} \mathrm{C}$ when in fact a portion of $\mathrm{CH}_{4}$ was released during warming from $0^{\circ} \mathrm{C}$ to $15^{\circ} \mathrm{C} . *$ runs where the PCS was configured to collect a water sample only, no core was taken.

In general, at a given volume, pressures on the synthetic volumepressure plot exceed observed pressures. This suggests nonequilibrium degassing, although the cause is unclear. During degassing of the PCS, internal pressure is maintained by gas exsolution of $\mathrm{CH}_{4}$ that is dissolved in water. The offset between synthetic and observed curves therefore suggests that insufficient gas has exsolved from water during degassing. Possible explanations include (1) water inside of the PCS is supersaturated with $\mathrm{CH}_{4}$ (perhaps because of absorption on sediment particles or because bubbles cannot nucleate in small pore space; B. Clennell, pers. comm., 1998); or (2) $\mathrm{CH}_{4}$ transfer between inner and outer chambers is slow such that $\mathrm{CH}_{4}$ concentrations are higher in the outer chamber. In any case, the offset reflects nonequilibrium conditions.

Five cores (Cores 164-995A-52P, 164-995A-60P, 164-995B-7P, 164-997A-18P, and 164-997A-55P) exhibit synthetic volume-pressure plots that are similar to observed volume-pressure plots (Figs. 4G, 4H, 4I, 4M, 4Q). It is unclear, however, why gas released from these particular cores is close to that predicted for equilibrium degassing in contrast to other cores. There are no obvious parameters, including average $\mathrm{CH}_{4}$ release rate, that distinguish these five cores (Tables 1 and 2), although we note that they generally have higher inferred pore-water $\mathrm{CH}_{4}$ concentrations in the inner chamber (Table 3).

Pressures on synthetic volume-pressure plots are less than observed pressures at a given volume for three cores (Cores 164-995A18P, 164-995A-36P, and 164-995A-48P; Figs. 4B, 4D, 4F). The likely reason for these atypical plots is that the total volume of gas was not recovered for these three cores (Table 2).
A simple synthetic volume-pressure plot cannot be generated for Core 164-997B-10P (Fig. 4R) because this core was not maintained at isothermal conditions. Temperatures inside of the PCS equilibrate with the ice bath at $0^{\circ} \mathrm{C}$ after about $60 \mathrm{~min}$ (Paull, Matsumoto, Wallace, et al., 1996, p. 123). Core 164-997B-10P must have been at a temperature greater than $0^{\circ} \mathrm{C}$ when gas was first released from this core after only $39 \mathrm{~min}$ (Table 1). An appropriate synthetic volumepressure plot for Core 164-997B-10P would have pressures at a given volume higher than expected for a core at $0^{\circ} \mathrm{C}$ (Fig. $\left.4 \mathrm{R}\right)$.

\section{Time-Pressure Plots}

Time-pressure plots for degassing of PCS cores at Sites 994, 995, and 996 have been presented by Paull, Matsumoto, Wallace, et al. (1996). Time-pressure plots for degassing of PCS cores at Site 997 can be constructed from data given by Dickens et al. (Chap. 43, this volume). Plots for Cores 164-997A-18P, 164-997A-49P, and 164997B-15P are shown in Fig. 5. All cores analyzed during Leg 164 have time-pressure plots with intervals where pressure increased over time after gas was released from the PCS and the valve to the container was closed (Fig. 5). However, Core 164-997A-18P probably did not have hydrate at in situ conditions (although see Egeberg and Dickens, 1999), and Core 164-997B-15P probably did not have hydrate at the start of experimental conditions (Table 3). Based on these data and observations, we conclude that "sawtooth characteristics" on time-pressure plots cannot be used to discriminate cores with $\mathrm{CH}_{4}$ hydrate. Our explanation is that gas coming out of supersaturated wa- 
A

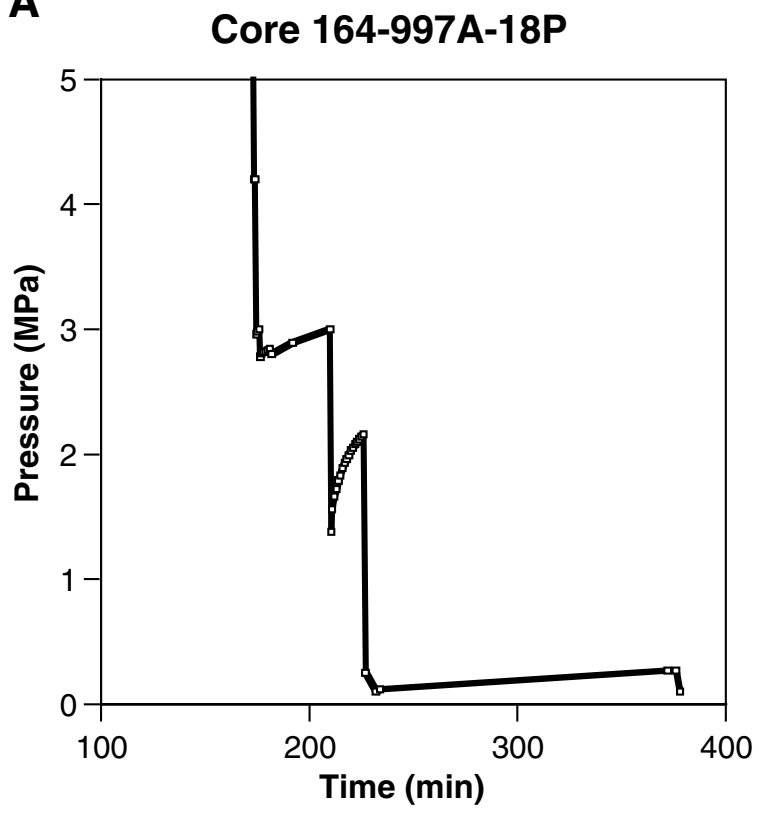

C

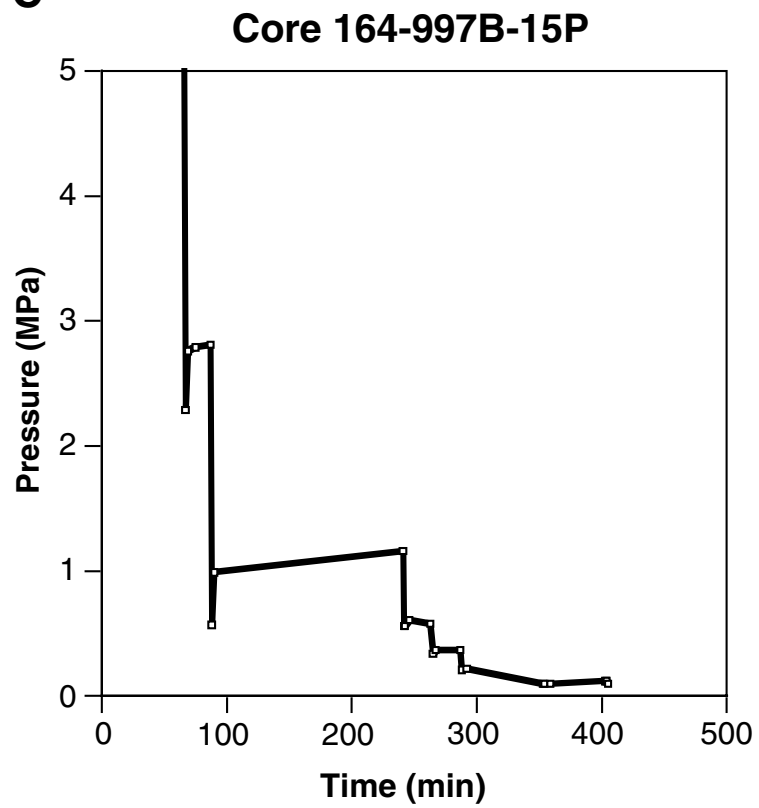

B

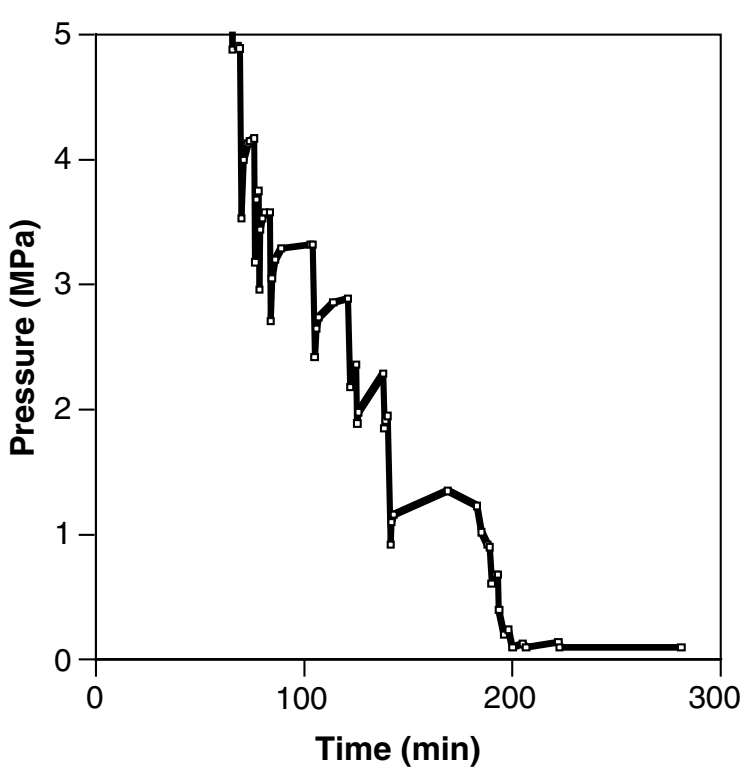

Figure 5. Time-volume plots for Cores (A) 164-997A-18P, (B) 164-997A-49P, and (C) 164-997B-15P. Core 164-997A-18P did not contain CH hydrate at in situ conditions nor at the start of gas-release experiments (Tables 1 and 3). Core 164-997A-49P contained $\mathrm{CH}_{4}$ hydrate at in situ conditions and at the start of gas-release experiments (Tables 1 and 3). Core 164-997B-15P did not contain $\mathrm{CH}_{4}$ hydrate at in situ conditions nor at the start of gas release experiments (Tables 1 and 3). However, this core would have contained $\mathrm{CH}_{4}$ hydrate in pore space at in situ pressure if the in situ temperature was at ${ }^{\circ} \mathrm{C}$. Note that for all cores "sawtooth profiles" are observed where pressure increases over time when the valve from the PCS to the manifold is closed.

ter will also give rise to a pressure increase after gas is released from a pressurized container.

Kvenvolden et al. (1983) presented time-pressure plots for three pressurized cores recovered at DSDP Site 533. All three of these plots showed "sawtooth characteristics" similar to those described above, in which pressure repeatedly increased over time after gas was released from the container and the valve to the container was closed. Although Kvenvolden et al. (1983) attributed this pattern to dissociation of $\mathrm{CH}_{4}$ hydrate inside of the pressurized container, they recognized the possibility that the pattern could be caused by "inefficient transfer of gas coming out of solution."

\section{Gas Release During Sediment Recovery}

An important observation made during Leg 164 is that sediment recovery using the XCB coring technique (Paull, Matsumoto, Wallace, et al., 1996, p. 314) was roughly inversely proportional to gas distribution directly determined from PCS experiments (Table 3; Dickens et al., 1997) and inferred from downhole logging, pore-water $\mathrm{Cl}^{-}$concentrations, and vertical seismic profiling (Holbrook et al., 1996; Paull, Matsumoto, Wallace, et al., 1996; Egeberg and Dickens, 1999). Presumably, large quantities of gas "blow" significant quantities of sediment out of the checkvalve at the top of the XCB when 
pressure is decreased quickly during core retrieval. This phenomenon can be dramatic. No sediment was recovered by the XCB from the critical depth interval of interest surrounding the bottom simulating reflector (BSR) at Site 997 (Paull, Matsumoto, Wallace, et al., 1996).

Information presented here suggests that significant volumes of gas are released from sediment pore water only after a specific threshold pressure is surpassed. The maximum threshold pressure for a sediment core depends largely on temperature and lies on the $\mathrm{CH}_{4}$ gas- $\mathrm{CH}_{4}$ hydrate-water equilibrium curve (Figs. 1, 2). With knowledge of the hydrotherm, it may be possible to estimate the depth in the water column where gas is rapidly released from sediment pore water as a core is being carried to the surface inside the drillstring. Slow wireline recovery across this water depth may significantly increase core recovery, because it would allow gas to escape more slowly with consequently less core disruption.

\section{CONCLUSIONS}

Previous authors have suggested that volume-pressure plots can be used to discriminate between pressurized cores with $\mathrm{CH}_{4}$ hydrate and those with only dissolved $\mathrm{CH}_{4}$. Volume-pressure plots were constructed for 20 PCS cores at Sites 994, 995, 996, and 997. Most of these plots conform to expected volume and pressure changes for cores with low $\mathrm{CH}_{4}$ concentrations at $0^{\circ} \mathrm{C}$ and no gas hydrate. This observation contrasts with other information that indicates relatively high $\mathrm{CH}_{4}$ concentrations and gas hydrate in sediment at these sites at in situ conditions. We conclude that conditions at the start of gas-release experiments with the PCS are sufficiently different than those at in situ conditions. In particular, $\mathrm{CH}_{4}$ concentrations decrease by at least $70 \%$ because of dilution with borehole water within the PCS. This dilution is of sufficient magnitude that $\mathrm{CH}_{4}$ hydrate-bearing sediment cores will show no indications of hydrate during PCS degassing experiments, because the hydrate will have decomposed during equilibration before degassing. The PCS cannot be used to detect unambiguously the presence (or absence) of gas hydrate in sediment at in situ conditions through volume-pressure (or time-pressure) relationships alone. However, the total gas volume released from a pressurized core of known porosity will render pore-volume gas quantities that, in conjunction with appropriate phase diagrams, can be used to estimate the abundance of gas hydrate and free gas (Dickens et al., 1997).

\section{ACKNOWLEDGMENTS}

We sincerely thank Tom Pettigrew and Matt Stahl for constructing the PCS; Matt Stahl, Jürgen Hohnberg, and Masa Kawasaki for operating the PCS during core collection; Hermann Wehner for collecting many PCS gas samples; Per Egeberg and Regis Thiery for dis- cussions regarding chemistry; and Ben Clennell and an anonymous reviewer for comments on the original manuscript. We also thank all scientists, engineers, and technicians who have worked previously with the PCS and PCB: our successes with the PCS are the cumulative result of significant work by many others. G. Dickens, P. Wallace, C. Paull, and W. Borowski were funded by the Joint Oceanographic Institutions U.S. Science Support Program. G. Dickens especially thanks all concerned for the last-minute invitation (gamble) to sail on Leg 164 and work on the PCS.

\section{REFERENCES}

Dickens, G.R., Paull, C.K., Wallace, P., and the ODP Leg 164 Scientific Party, 1997. Direct measurement of in situ methane quantities in a large gas-hydrate reservoir. Nature, 385:427-428.

Dickens, G.R., and Quinby-Hunt, M.S., 1994. Methane hydrate stability in seawater. Geophys. Res. Lett., 21:2115-2118. 1997. Methane hydrate stability in pore water: a simple theoretical approach for geophysical applications. J. Geophys. Res., 102:773783.

Duan, Z., Møller, N., Greenberg, J., and Weare, J.H., 1992. The prediction of methane solubility in natural waters to high ionic strengths from $0^{\circ}$ to $250^{\circ} \mathrm{C}$ and from 0 to 1600 bar. Geochim. Cosmochim. Acta, 56:14511460.

Egeberg, P.K., and Dickens, G.R., 1999. Thermodynamic and pore water halogen constraints on gas hydrate distribution at ODP Site 997 (Blake Ridge). Chem. Geol., 153:53-79.

Handa, Y.P., 1990. Effect of hydrostatic pressure and salinity on the stability of gas hydrates. J. Phys. Chem., 94:2652-2657.

Holbrook, W.S., Hoskins, H., Wood, W.T., Stephen, R.A., Lizzarralde, D. and the Leg 164 Science Party, 1996. Methane gas-hydrate and free gas on the Blake Ridge from vertical seismic profiling. Science, 273:18401843.

Hunt, J.M., 1979. Petroleum Geochemistry and Geology: San Francisco (W.H. Freeman).

Kvenvolden, K.A., Barnard, L.A., and Cameron, D.H., 1983. Pressure core barrel: application to the study of gas hydrates, Deep Sea Drilling Project Site 533, Leg 76. In Sheridan, R.E., Gradstein, F.M., et al., Init. Repts. DSDP, 76: Washington (U.S. Govt. Printing Office), 367-375.

Paull, C.K., Matsumoto, R., Wallace, P.J., et al., 1996. Proc. ODP, Init. Repts., 164: College Station, TX (Ocean Drilling Program).

Pettigrew, T.L., 1992. The design and operation of a wireline pressure core sampler (PCS). ODP Tech. Note, 17.

Tohidi, B., Danesh, A., and Todd, A.C., 1995. Modelling single and mixed electrolyte solutions and its application to gas hydrates. Chem. Eng. Res. Design, 73:464-472.

Date of initial receipt: 27 April 1998

Date of acceptance: 13 January 1999

Ms 164SR-210 